\title{
O QUE É PRosódia?
}

\author{
D. Robert Ladd | CV | D.R.Ladd@ed.ac.uk
}

The University of Edinburgh

Tradução

Leticia Rebollo Couto | Lattes | leticiarcouto@yahoo.fr Universidade Federal do Rio de Janeiro

Izabel Christine Seara | Lattes | izabel.seara@gmail.com, izabels@linse.ufsc.br Universidade Federal de Santa Catarina

\section{INTRODUÇÃO PELAS TRADUTORAS}

É um grande prazer apresentar uma versão em português do texto de Robert Ladd Defining Prosody, proferido na mesa redonda da ABRALIN, Prosody: Linguistic, expressive, or both? Esta mesa foi proposta e coordenada por Juan Manuel Sosa no dia 9 de março de 2017, na Universidade Federal Fluminense (UFF). O texto traduzido faz parte, na sua versão integral, da última obra de Robert Ladd, Simultaneous Structure in Phonology publicada em 2014 pela Oxford University Press, a quem agradecemos ter-nos cedido os direitos de publicação. ${ }^{1}$

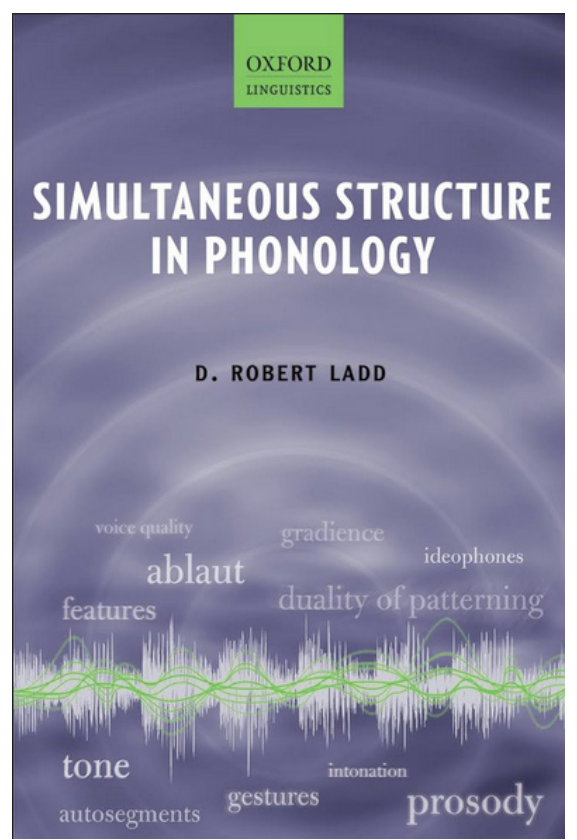

\footnotetext{
${ }^{1}$ Traduzido de: LADD, D. Robert. Defining prosody, In: LADD, D. Robert. Simultaneous Structure in Phonology. Oxford, Oxford University Press, p. 57-84, 2014. Reproduzido com permissão do Licenciante através do PLSclear.

(C) Working Papers 2019 - Todos os direitos reservados
} 
Trata-se do capítulo 3 da referida obra sobre a estrutura simultânea da fonologia, composta de seis capítulos: (1) Gesto, traços e autossegmentos, (2) Fonética na fonologia, (3) Definindo prosódia, (4) Modulações, (5) Sobre a dualidade da padronização e (6) Eventos fonológicos (segmentação, eventos simultâneos e paralelos).

Robert Ladd é quem teoriza o modelo de fonologia prosódica a partir da tese de Pierrehumbert (1980), transformando o sistema de notação ToBI (Tones and Break Indices) - para o inglês norte-americano - num modelo robusto que ele denomina de autossegmental e métrico, também conhecido como modelo AM (Autosegmental Metrical Theory). Sua obra Intonational Phonology, segundo dados do Google Scholar consultado em julho de 2019, tem pelo menos 4800 citações (LADD, 1996, 2008). As contribuições desse modelo para a descrição da entoação e acentuação em diversas línguas são inúmeras, incluindo a proposta de Daniel Hirst (Momel/Insint), com importantes descrições para o português do Brasil (MORAES, 1998).

Como Ladd (2014) discute logo no primeiro capítulo de sua última obra "autossegmento" não é um termo simplesmente equivalente a "traço". O comportamento autossegmental é um fenômeno específico, e não simplesmente um sub-tipo de espraiamento de traços. O autor propõe voltar às intuições originais de Leben (1973) e Goldsmith (1976), evitando seguir a lógica teórica que conduz à geometria de traços, para poder formular perguntas de pesquisa que têm o potencial de deixar clara esta diferença. Um exemplo da utilidade desta distinção está na diferenciação entre harmonia vocálica, nas línguas que têm essa harmonização, e a simples assimilação. Pois, a primeira é gramatical enquanto que a segunda não (NEVINS, 2010).

Agradecemos a imensa generosidade do autor por permitir-nos apresentar seu texto em português para estudantes, professores e pesquisadores brasileiros de fonética e fonologia. Acreditamos que seja a primeira tradução deste autor ao português publicada no Brasil, o que nos honra muitíssimo. Além do interesse evidente para prosodistas, a leitura deste artigo pode interessar estudiosos da lexicografia, da tradução ou das letras clássicas, considerando a descrição minuciosa apresentada pelo autor da saga terminológica dos nome prosódia e do adjetivo prosódico/a, bem como o detalhamento a metodológico pela busca da mudança de sentido e sua descrição.

O texto está dividido em seis partes que renomeamos em português da seguinte maneira: (1) Prelúdio lexicográfico, (2) A história da prosódia, (3) A prosódia como miscelânea, (4) Algumas indicações que podem ser relevantes para a definição de prosódia, (5) Então, o que é prosódia? e (6) Apêndices de definições. 
Nestas seis seções o autor do ineludível Intonational Phonology (1996, 2008), texto seminal para os estudos da entoação e da prosódia, nos brinda com um panorama da evolução de sentido e da extensão do termo prosódia e suas interfaces, tema deste número monográfico da revista Working Papers em Linguística. O autor revisa, com erudição linguística e rigor metodológico, a trajetória de sentido deste termo iniciando com suas origens clássicas, assinala a importante inflexão de 2002 com o lançamento do Congresso Internacional de Prosódia da Fala (Speech Prosody) - do qual participam desde então muitos pesquisadores brasileiros, e chega às duas grandes linhas de pesquisa que orientam, nos dias de hoje, o número crescente de trabalhos em fonética e fonologia e que têm como objeto de estudo fenômenos ditos prosódicos. Boa leitura!

\section{PRELÚDIO LEXICOGRÁFICO}

Foi por volta de 2002 - o ano em que a série de congressos sobre Prosódia da Fala (Speech Prosody) começou na França, sediada em Aix-en-Provence - quando eu percebi que o dicionário online de Inglês de Oxford: Oxford English Dictionary (OED) continuava oferecendo a mesma definição de prosódia que aquela publicada em 1930, na primeira edição impressa deste dicionário. Essa definição original, omitindo as citações e alguns detalhes irrelevantes, dizia:

1. A ciência da versificação, parte dos estudos da linguagem que trata da composição métrica, anteriormente reconhecida como uma parte da gramática... incluindo também o estudo da pronúncia das palavras (agora chamada fonologia ou fonética) especialmente em relação à versificação. [primeira citação cerca de 1450]

2. A pronúncia correta das palavras; a enunciação dos sons de uma língua de acordo com as suas regras; observando as leis da prosódia. sentido pouco frequente [primeira citação 1616]

A segunda edição de 1989, que foi a que eu encontrei online, por volta de 2002, mantém estas duas definições praticamente da mesma forma, e acrescenta:

3. Linguística. Segundo as teorias de J.R. Firth e seus seguidores: a prosódia diz respeito a um traço fonológico que tem como domínio mais do que um segmento. A Prosódia inclui a categoria de traços "suprassegmentais", tais como entoação, acento e juntura, mas também alguns traços vistos como segmen- 
tais, na teoria fonêmica, como por exemplo a palatalização, o arredondamento dos lábios ou a nasalização.

Ora, que eu saiba, nenhum dos participantes do congresso de Aix-en-Provence, naquela primavera de 2002, tinha em mente discutir versificação ou modelos fonológicos de Firth. Em 1989 (ou ainda mesmo em 2002), no referido dicionário de Oxford (OED) não há nenhuma indicação sobre o novo sentido do termo prosódia que já estava bastante difundido e que tinha amplamente superado seus primeiros sentidos. Foi só algum tempo, depois de 2002 - e eu não sei exatamente quando - que a terceira definição foi mudada para:

4. Fonologia. Um traço fonológico suprassegmental tal como entoação e acento. E ainda: esses traços vistos em seu conjunto; os padrões de acento e entoação em uma língua.

Em usos anteriores algumas vezes (como no trabalho de J.R. Firth (18901960) e seus seguidores) foi aplicado a alguns traços definidos pela teoria fonêmica standard como segmentais, tais como palatalização, arredondamento dos lábios e nasalização [inter-referências para sentidos relevantes da prosódia foram omitidos]

Desenvolvimentos similares podem ser observados em muitas outras línguas europeias para os termos correspondentes a prosódia ou prosódico/a; entretanto, nos anos 90, a maioria dos dicionários apresentava apenas as duas definições tradicionais equivalentes aos dois primeiros sentidos do dicionário de Oxford (OED), e só depois passam a registrar algo mais equivalente com o sentido que pretendiam os organizadores do congresso sobre Prosódia da Fala (Speech Prosody).

\section{A HISTÓRIA DA 'PROSÓDIA'}

O que ocorreu com a trajetória de sentido do termo prosódia parece uma simples história de inércia lexicográfica face ao rápido desenvolvimento da terminologia técnica. Entretanto, acho que há mais do que isso neste caso. Uma breve incursão pelo modo como prosódia e prosódico/a foram sendo usados sugerem algum tipo de fatalidade histórica através das mudanças graduais de sentido desses termos. Mas no fim das contas, o que vemos mesmo é a história repetindo-se uma e outra vez. ${ }^{2}$

\footnotetext{
2 A Seção 2 deste artigo "A história da prosódia" está fortemente baseada nas leituras de Allen (1973, p. 3-16) e Crystal (1969, p. 20-90), bem como em alguns apontamentos filológicos e bibliográficos de Nina Grønnum, John Joseph, Meg Laing e Henry Stevens. Quaisquer imprecisões ou interpretações errôneas são da minha inteira responsabilidade.
} 


\subsection{O passado histórico clássico}

Se levarmos em conta as palavras equivalentes em outras línguas europeias, além das formas que já vimos para o inglês, descobrimos que o primeiro sentido de prosódia, lido no Dicionário de Oxford para o Inglês (OED) - a ciência da versificação - não é o sentido original do termo em grego. O termo prosōdia [ $\pi \rho \circ \sigma \omega \delta \delta$ ía] foi usado no século VI a.C. por gramáticos gregos e filósofos, incluindo Aristóteles e Platão, para referir-se aos acentos da palavra do grego clássico. Esta forma está claramente composta pelo prefixo

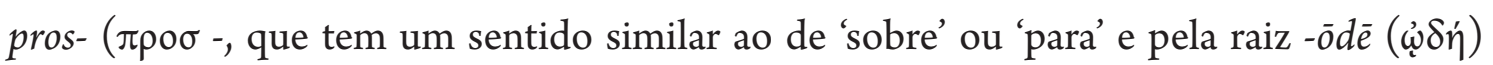
'canção' e significa algo como o acompanhamento musical - a canção sobre - os sons segmentais da palavra. A centralidade do sentido "acento da palavra" é mais tarde mostrada pelo fato de que no latim a palavra accentus, como muitos termos gramaticais do latim é um calco direto ou uma tradução literal do grego prosōdia: pela combinação do ad 'para' + cantus 'canção' se forma a palavra accentus por regras regulares de derivação fonológica. É importante notar que nesse sentido, tanto em grego prosōdia quanto em latim accentus os termos foram correntemente utilizados em suas formas plural e singular; os acentos da palavra eram denominados 'prosodias', ou seja, eventos fonológicos que ocorrem num ponto específico da palavra.

No século II a.C., o termo também se refere a marcas escritas que começaram a ser usadas para indicar os acentos do grego clássico. Durante o período clássico propriamente dito, ou seja, entre os séculos VI a IV a.C, os acentos não eram marcados. Posteriores marcações foram adicionadas durante o período bizantino; no século II a.C., prosōdia também foi usada (nos escritos de Sextus Empiricus) para referir-se a outras propriedades fonemicamente distintivas que não eram indicadas na escrita durante o período clássico mas para as quais marcas diacríticas foram criadas. Além dos acentos de palavras, estas marcas incluíam duração vocálica (que aliás sempre tinha sido indicada por diferentes letras para a distinção curta e longa no par /e/ e /o/ mas que não era indicada para /i a u/) bem como a presença ou a ausência de uma aspiração inicial (a diferença entre "espírito áspero" e "espírito brando"). Numa extensão de sentido ainda maior, o termo provavelmente se refere a vários esquemas de notação - precursores da pontuação europeia moderna - que tinham sido desenvolvidos para auxiliar os estudantes de retórica a falar com mais eficácia a partir de textos escritos indicando os agrupamentos naturais de palavras em sintagmas e unidades maiores.

A inflexão do âmbito da prosódia para o da estrutura do verso - primeiro sentido do Dicionário de Inglês de Oxford, Oxford English Dictionary (OED), parece ter acontecido durante a Idade Média, ou talvez quando a palavra foi importada para o inglês e outras línguas europeias. É possível inclusive que essa mudança de sentido se deva a uma confu- 
são etimológica. Há uma outra palavra do grego antigo prosodios ( $\pi \rho \circ \sigma o ́ \delta เ \varsigma \varsigma)$, no sentido de 'processional', que não está baseada na raiz ōdē (⿳亠丷厂彡⿱㇒') 'canção' (com um /o/ longo) mas em hodos (ö $\delta \mathrm{o})$ 'caminho' (com um /o/ curto). O adjetivo derivado prosodiakos ( $\pi \rho \circ \sigma \circ \delta\llcorner\alpha \kappa o ́ \varsigma)$ era aplicado a um tipo de metro adequado para as canções processionais, e a um tipo de pé característico desse metro. O Léxico Grego-Inglês recopilado por Liddell

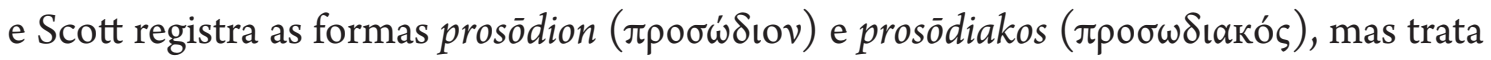
ambas como erros (falsa lectio) atribuídos às formas com /o/ curto. O OED sugere que essa confusão começa já com o latim, que, diferentemente do grego, tem apenas uma letra tanto para a realização curta quanto longa de /o/. Ou seja, o fato de que prosodiakos fosse usado para descrever um tipo de metro poético pode ter-se dado devido a uma relação falsa com prosódia. Mesmo que a mudança de sentido para versificação fosse decorrente de uma confusão, é fato que o sentido de prosōdia foi se expandindo gradativamente durante os períodos clássico e bizantino. De uma etapa inicial na qual apenas se referia ao acento de palavra em grego, o sentido foi se estendendo para referir-se a traços como alongamento e aspiração e, além disso, provavelmente, também a traços de agrupamento e fraseamento.

\subsection{As concepções da Linguística no século $X X$}

A expansão gradativa dos termos clássicos se vê refletida de maneira notavelmente próxima na evolução das palavras prosódia e prosódico/a, e suas contrapartes em muitas outras línguas europeias, nos estudos de linguística ao longo do século XX. Começando logo no início do século, alguns linguistas começam a usar esses termos (especificamente a forma adjetival prosódico $/ a^{3}$ ) para se referir à distinção de fonemas no nível da palavra que não é expressa por contraste entre segmentos fonéticos - isto é, algo bastante próximo ao sentido original do grego prosōdia. As primeiras instâncias do uso do adjetivo prosódico/a que eu encontrei em inglês estão num artigo de Sapir (1923, p. 137) sobre as orações relativas nas línguas athabascanas (Alasca/Estados Unidos). Nesse artigo, Sapir afirma que duas formas podem ser distinguidas por uma "diferença prosódica (de acento ou pitch)”. Praticamente na mesma época, um dos seguidores de Sapir (de ANGULO, 1929 , p. 117) propõe prosódia como um termo rotulador para a aplicação de tais dis-

\footnotetext{
${ }^{3}$ Definitivamente há uma assimetria entre o nome e o adjetivo na bibliografia. Enquanto o uso adjetival ("traços prosódicos", etc.) pode ser encontrado no começo dos anos 40 , no trabalho de vários proeminentes linguistas universitários, o nome parece ter mantido o seu sentido primeiro, "ciência da versificação" por muito mais tempo em muitas línguas europeias, sendo que outros usos linguísticos permanecem raros até os anos 70. Provavelmente, num contexto linguístico, o nome prosódia se presta a um maior risco de ambiguidade, enquanto que o adjetivo prosódico/a pode ser combinado com outros nomes de tal forma que se evite a sugestão do sentido poético.
} 
tinções em processos morfológicos; sendo que esta proposta cobria também a quantidade (isto é, distinções de duração vocálica). Usos similares, especialmente do adjetivo prosódico/a, podem ser encontrados em outros linguistas próximos ao círculo de Sapir, é o caso por exemplo de Morris Swadesh (1934, 1949), e foram subsequentemente encontrados nos primeiros trabalhos de Trager e Bloch (1941). Entretanto, Trager e Bloch tendem a usar suprassegmental em seus trabalhos posteriores, com praticamente o mesmo sentido, o que se torna uma marca registrada da terminologia dita bloomfieldiana. No que diz respeito a outras línguas, a edição de Marouzeau (1933) do seu Lexique de la Terminologie Linguistique, que registra usos de termos técnicos em francês, alemão e inglês, contempla uma entrada para o nome prosódia (prosodie), considerando apenas o sentido clássico grego e o sentido relacionado à métrica e à versificação. Com o passar do tempo, na edição de 1943, a entrada foi revisada e adicionando o uso que os fonólogos fazem do termo para referir-se às "propriedades melódicas, dinâmicas e de quantidade relacionadas às propriedades fonéticas de uma língua” (a tradução é do autor). $\mathrm{O}$ adjetivo alemão prosodisch é usado sem comentários por Trubetzkoy em seus Princípios (Principles). Especialmente no capítulo 4, seção 5, referindo-se principalmente ao que ele chama de traços "ritmo-melódicos". Para Trubetzkoy, traços prosódicos definitivamente incluem a distinção de quantidade.

Em suma, os termos prosódico/a e (em menor extensão) prosódia, e seus equivalentes em outras línguas, já eram bastante conhecidos, tanto na linguística europeia quanto na norte-americana, no começo dos anos 40. Geralmente se referiam a distinções de tom e de acento no nível da palavra, e pelo menos para alguns linguistas em seus escritos, também de quantidade. Pouco depois, esses termos passam a ser aplicados a fenômenos fonéticos que vão além do nível da palavra também, principalmente envolvendo agrupamentos de palavras em sintagmas, de sintagmas em enunciados, e assim por diante no processo de fraseamento. Em um primeiro estudo, já em 1934, Swadesh (1934, p. 122) se refere à "prosódia da frase" enquanto Trager e Bloch (1941) foram um dos primeiros a mencionar "juntura" (pistas fonéticas para fronteiras) conectada com acento e pitch. Logo em seguida, o termo conheceu uma notável expansão, sobretudo no contexto do trabalho clínico sobre afasia e outros distúrbios da fala e da linguagem, bem como em trabalhos psicológicos e psiquiátricos lidando com a expressividade do falante, afetos e personalidade. Pesquisadores desses campos (e mais recentemente, pesquisadores voltados para aplicações tecnológicas de automação, tais como síntese e reconhecimento da fala) já têm assumido há muito tempo como uma premissa básica de que há uma diferença 
fundamental entre o conteúdo proposicional (o que é dito) e tudo o que é veiculado pela realização sonora da fala em si (como é dito acusticamente). Esta distinção, que Crystal (1969, p. 76) caracteriza como "verbal" vs. "vocal", começa já no início do século XX (para uma análise mais exaustiva ver Crystal, 1969, p. 62-90) e ainda é um importante vetor das pesquisas hoje em dia (para análises mais aprofundadas ver Schroeder, 2001; Schriberg e Stolke, 2004 na área tecnológica). O uso dos termos prosódia e prosódico/a para considerar o lado não verbal desta distinção parece iniciar, digamos assim, a partir da metade do século XX. Uma instância pioneira deste uso - talvez sua fonte mesma é um artigo ainda citado sobre "disprosódia" escrito por Georg Monrad-Krohn (1947). Este artigo de Monrad-Krohn foi o primeiro relatório científicamente respeitável sobre a "síndrome do sotaque estrangeiro" e identificou distúrbios do ritmo da fala e da melodia, e não problemas segmentais de articulação, como o principal fator de reconhecimento e percepção do sotaque estrangeiro.

Ainda assim, provavelmente por causa da competição ou eventual confusão potencial com o sentido tradicional referente à métrica e à versificação e (ao menos na América do Norte) por causa da disponibilidade do termo sinônimo suprassegmental, o uso linguístico de prosódia e prosódico/a permanece relativamente restrito até os anos 70 . Em inglês, é possível que a expansão do sentido linguístico tenha sido inibido pela aplicação idiossincrática dos termos prosódia e prosódico/a no trabalho de J. R. Firth, cuja "Escola de Londres" foi extremamente influente na linguística britânica dos anos 30 aos 70 . Por exemplo, Firth (1948) rejeita a forte tendência de base segmental da idealização fonêmica, como foi desenvolvida nos anos 30 e 40, e encampa seriamente a ideia de que muitas propriedades fonéticas se aplicam a trechos de fala mais longos do que um simples segmento. Firth designa estas propriedades como prosódia, usando o termo como um nome com plural prosódias, como no grego clássico (o que ainda causa consternação, muitos anos depois, ao corretor ortográfico da Microsoft). As representações fonológicas firthianas eram uma complexa combinação de prosódias e do que foi chamado de "unidades fonemáticas" agrupamentos por tamanho do segmento de propriedades fonéticas irredutivelmente locais). A abordagem fonológica firthiana ficou conhecida durante um bom tempo como "análise prosódica" ou "fonologia prosódica". Para uma revisão mais aprofundada das bases da fonologia firthiana ver Anderson (1985) ou Ogden e Local (1994), para sua exemplificação ver os diversos trabalhos de Palmer (1970) e sobretudo os de Henderson (1949). Firth e seus seguidores estavam particularmente interessados em fenômenos tais como a harmonia vocálica e o espraiamento da nasalização, o que 
proporciona evidente justificativa para postular unidades fonológicas abstratas que estão ligadas a domínios maiores do que o dos segmentos. Algumas das ideias de Firth foram retomadas ou redescobertas e desenvolvidas em trabalhos descritivos nos anos 70 e 80 sob a tradição da fonologia autossegmental ${ }^{4}$, mas não tiveram um papel direto na rápida mudança de sentido do termo prosódia nos anos 70, sendo que o uso firthiano específico do termo, como é adequadamente tratado pelo OED em sua última definição, já não é mais o uso corrente.

Foi só quando Halle e Keyser publicaram o seu primeiro trabalho sobre a métrica do inglês em 1966 e desencadearam intensos debates universitários (BEAVER, 1968; KEYSER, 1969; SLEDD, 1969; WIMSATT, 1970; STANDOP, 1972) que o atual uso linguístico do termo prosódia começou a se delinear. Relacionando fatos da poética e ideias linguísticas sobre a estrutura fonológica dos enunciados, o trabalho de Halle e Keyser sugere temas comuns entre o novo sentido linguístico da prosódia e sua noção poética tradicional. Essa mistura de considerações fonológicas e poéticas foi levada adiante por Mark Liberman em sua tese doutoral (1975) que esboçou conexões explícitas entre as configurações musicais do texto e o que ele denominou "associações tonais do texto" na entoação. $\mathrm{O}$ trabalho pioneiro de Liberman chamou a atenção da área para a importância da estrutura hierárquica na análise da entoação e do acento, e nos anos 80 uma grande massa de trabalhos foi realizada sob a rubrica de "fonologia métrica” e "fonologia prosódica"s. Muitos dos trabalhos mais importantes nessa tradição apareceram durante esse período, incluindo os trabalhos de Selkirk (1984), Nespor e Vogel (1986), Pierrehumbert e Beckman (1988), todos focalizando diferentes aspectos do papel que a estrutura hierárquica desempenha na fonologia. É importante ressaltar que os fenômenos tratados nesses trabalhos não se limitam apenas à entoação e ao acento, incluem também os efeitos das fronteiras fonológicas tais como sândi externo e a "juntura" de Trager e Bloch. Um estudo quantitativo e evidente da bibliografia, baseado apenas numa análise preliminar das entradas em Google Scholar ${ }^{\mathrm{TM}}$ consultadas em maio de 2011 (o detalhamento encontra-se na seção 6 deste artigo), claramente assinala que a mudança de sentido e de uso do termo começa com o trabalho de Halle e Keyser, e que a noção poética de prosódia e prosódico/a começa a ser virtualmente obsoleta em torno de 1985.

Uma objeção possível para a síntese que apresentei aqui brevemente é que o sentido lato dos termos linguísticos já pode ser assinalado como o sentido corrente desses

\footnotetext{
${ }^{4}$ Para aprofundar a questão, ler Capítulo 1, Gesto, traços e autossegmentos, em Ladd (2014).

${ }^{5}$ Não deve ser confundido com o uso de "fonologia prosódica" atribuído ao trabalho descritivo firthiano.
} 
termos nas línguas escandinavas antes mesmo do século XX. Ambos os termos prosodi e prosodisk foram usados extensivamente nos trabalhos do gramático sueco Adolf Noreen, principalmente no seu trabalho mais importante Vårt Språk (Nossa Língua), que foram publicados em vários volumes, a partir de 1903. Sob o título prosodi, Noreen discute traços de intensidade ou proeminência, melodia e quantidade vocálica, bem como estrutura silábica e fonotática. Segundo Jakobson e Waugh (1979, p. 142f) Noreen é o autor da ideia de uma distinção fundamental entre traços fonológicos "prosódicos" vs. "inerentes", que Jakobson desenvolve posteriormente no seu trabalho (ver seção 4.4 deste artigo). Entretanto não fica muito claro nas discussões de Jakobson e Waugh se eles consideram que a inovação de Noreen consiste no uso atual do termo prosodi ou no esboço da distinção dicotômica "prosódico" vs. "inerente". Contudo, é possível que em certos aspectos o uso do termo já fosse familiar para os pesquisadores escandinavos, já familiarizados, em suas próprias línguas, com os fenômenos no nível da palavra, similarmente ao caso dos acentos no grego clássico. O gramático dinamarquês Jens Høysgaard, citado no grande dicionário dinamarquês do século XX, Ordbog over det Danske Sprog, usou o termo prosodi em 1769 para se referir ao acento e à quantidade nas palavras, mas não fica claro se o autor pretendia que o uso do termo fosse um ponto de partida para o uso métrico/poético. Pode ser, ou não, uma coincidência o fato de que Monrad-Krohn, aquele que cunhou o termo "disprosódia" para descrever traços da fala afetados pela síndrome do sotaque estrangeiro, fosse um falante de norueguês, e para ele pode ter parecido "disprosódia" uma extensão natural do uso corrente já estabelecido em línguas escandinavas para "prosódia”. Todavia, mesmo se esse uso já era familiar nas línguas escandinavas, parece bastante claro que não era corrente nem em inglês, nem em francês e nem em alemão antes dos anos 20.

\section{A PROSÓDIA COMO UMA MISCELÂNEA}

Em menos de um século, os termos linguísticos modernos prosódia e prosódico/a parecem ter passado por um desenvolvimento paralelo ao do termo em grego antigo prosōdia. Partindo de um referente específico relacionado ao nível tonal da palavra ou a traços acentuais, tanto os termos clássicos quanto os modernos passam por uma extensão de sentido para incluir nesse âmbito outros fenômenos, normalmente não indicados pela escrita, incluindo em ambos os casos traços de quantidade e pistas de agrupamentos de palavras em sintagmas e frases. Uma interpretação possível para esse paralelo é que estudiosos modernos redescobriram informações úteis para a organização da fonologia, e que há uma certa unidade natural na gama de aspectos desses elementos, agrupados num 
mesmo conjunto graças à expansão de sentido dos termos. Outra interpretação é que a expansão de sentido simplesmente reflete o enviesamento induzido na época clássica pela cultura escrita alfabética e na era moderna pelas transcrições em IPA: em ambos os casos, tudo o que não fosse escrito pelas letras de consoantes e vogais deveria ser considerado como um outro tipo de elemento fonológico.

\subsection{A Prosódia como um artefato alfabético?}

Aparentemente, justifica-se considerar as expansões paralelas de prosōdia e de prosódia como um artefato da cultura escrita alfabética. A idealização segmental que fundamenta qualquer tipo de escrita alfabética, incluindo as transcrições em IPA, está muito pouco adaptada para representar certos traços fonológicos considerados como "prosódicos”. E isto se deve ao fato de que as representações alfabéticas estão ordenadas em cadeias sucessivas ou sequências de elementos atomizados ${ }^{6}$, e enquanto tais são inadequados para representar várias propriedades fonéticas imediatamente perceptíveis da fala.

Em primeiro lugar, vamos considerar a duração. A escrita alfabética, efetivamente, exclui qualquer indicação de tempo: a única propriedade temporal que conta, formalmente falando, é a da ordem linear ou a ordem de precedência. Há formas de incluir distinções fonêmicas categóricas, tais como vogais curtas e longas, incluindo marcas diacríticas (ver em IPA [:] ou o acento agudo na ortografia do húngaro), letras diacríticas (a letra $<\mathrm{h}>$ subsequente à letra de uma vogal na ortografia do alemão), e o recurso à escrita de dois símbolos idênticos adjacentes (como por exemplo a ortografia do finlandês). Entretanto, tais estratégias não dão conta de representar traços que variam gradativamente no tempo e que têm outras funções linguísticas, tais como as pistas de acento e fraseamento. Também não conseguem refletir algumas propriedades específicas da duração de segmentos tais como o fato de que as fricativas são geralmente mais longas do que as oclusivas. Esses traços são integrados sob a égide de transcrições abstratas - como os símbolos de fronteira nas transcrições em IPA e a pontuação na escrita alfabética corrente - ou são, em muitos casos, simplesmente ignorados. Nesse sentido, é interessante observar que os símbolos de fronteira, incluindo o símbolo para "ligação (ausência de ruptura)” são todos listados sob o título de "Suprassegmentais".

Agora vamos considerar o pitch. Outra consequência que decorre do fato de que a escrita alfabética se organiza a partir de cadeias ou sequências sucessivas é que este

\footnotetext{
${ }^{6}$ Optamos por traduzir ao longo do texto o termo strings como "cadeias ou sequências" mantendo presente tanto o termo mais utilizado em matemática e programação "cadeias", quanto o termo mais utilizado em linguística "sequências". [Nota das tradutoras]
} 
ordenamento dificulta a representação de distinções fonológicas que estão baseadas na sobreposição ou mesmo em arranjos sem ordem sequencial de diferentes elementos. Se temos que nos limitar a uma cadeia ou sequência de símbolos para os quais essa ordem linear de símbolos representa a sucessão no tempo, onde colocamos, então, o símbolo representando um fonema (tal como o tom por exemplo) que ocorre concomitantemente com outro fonema ou com outros fonemas? ${ }^{7}$ Em alguns sistemas de escrita alfabética aplicados a línguas tonais (ver a língua dinca, dos povos do Sudão do Sul), a resposta é simples, não se representa em nenhum lugar, enquanto que em outros (notoriamente na língua vietnamita, língua nacional e oficial do Vietnã) usamos marcas diacríticas. De um jeito ou de outro, o tom parece ser, deste modo, um fenômeno à parte.

A impressão de que a prosódia é um pouco mais do que o resíduo da transcrição segmental é reforçada pela quase sinonímia dos termos prosódico e suprassegmental. Como vimos anteriormente, linguistas bloomfieldianos tais como Trager e Bloch adotaram o segundo termo - que toma de forma transparente a idealização segmental da fonética como um ponto de partida - em detrimento do primeiro. Durante os anos 50 e mesmo nos 60, o termo suprassegmental foi a forma corrente para se referir coletivamente aos traços de pitch, acento e duração, pelo menos na América do Norte, e o termo ainda é razoavelmente comum - especialmente nas definições de prosódia! A intercambiabilidade virtual de ambos os termos pode ser observada no livro de Lehiste Suprasegmentals, que se inicia com a frase "O estudo da prosódia” (LEHISTE, 1970, p. 1). É no mínimo plausível dizer que a idealização segmental da fonética deu lugar a uma visão generalizada de que os traços suprassegmentais representam um conjunto coerente de fenômenos.

Certamente deve haver outras razões pelas quais as distinções suprassegmentais são frequentemente excluídas da escrita alfabética. Uma delas é a circunstância histórica que fez com que a escrita alfabética aparecesse numa parte do mundo em que as distin-

\footnotetext{
7 Só pode existir uma resposta arbitrária para esta pergunta, como bem pode ser visto pelas práticas de linguistas, alfabeticamente orientados, ao descrever a fonologia de línguas tonais. Na coletânea organizada por Thurgood e LaPolla (2003) sobre línguas sino-tibetanas, coletânea esta em que cada capítulo é destinado à descrição de uma língua, a maioria dos autores de capítulos individuais chegam a descrever o “padrão silábico" ou o "modelo silábico" de línguas que tinham, em sua grande maioria, marcação de tom lexical. Poucos autores (como por exemplo Bradley, sobre a língua lisu, capítulo 14) apresentam fórmulas como C(G)VT (isto é, consoante, glide opcional, vogal e tom), com o tom linearizado no final, depois da especificação das posições segmentais. Outro autor (Mazaudon, sobre a língua tamang, capítulo 18) apresenta uma fórmula similar, mas com o tom linearizado no começo, antes dos segmentos. Enquanto que ainda, um terceiro autor (Solnit sobre a língua do leste kayah li, capítulo 38) escreve C1(C2)(G)V/T, usando explicitamente o / entre o símbolo V e o T para marcar a "ocorrência simultânea”. Em dois capítulos (Bauer e Mathews sobre o cantonês, capítulo 9; e Wiersma sobre a língua bai de Yunnan, capítulo 40) encontramos representações multilineares. A solução mais comum é simplesmente apresentar fórmulas mostrando apenas os segmentos: $(\mathrm{C})(\mathrm{G}) \mathrm{V}(\mathrm{G})$ (como por exemplo Gong sobre a língua tangut, capítulo 37) e discutir o tom separadamente.
} 
ções fonéticas de tom eram pouco frequentes. Outra razão alternativa possível é a base articulatória das distinções suprassegmentais. Os gestos supralaríngeos, que originam as vogais e especialmente as consoantes, são facilmente acessíveis à própria percepção e auto observação de seus movimentos, como qualquer um que tenha realizado trabalhos práticos de fonética bem sabe. É fácil ter consciência da diferença articulatória entre, digamos, $[\mathrm{m}]$ e $[\mathrm{n}]$, e consequentemente sentir a necessidade de estabelecer símbolos alfabéticos diferentes para fonemas distintos, com base na percepção dessa diferença. Por outro lado, é mais difícil ter consciência da forma como produzimos distinções de pitch e acento, e consequentemente, talvez isso faça que seja menos evidente a necessidade de representar esse tipo de distinções.

Contudo, parece ser nitidamente verdade que traços fonéticos correlatos como pitch e duração, que são o centro da maioria das definições implícitas de prosódia, são difíceis de representar, dadas certas propriedades formais da escrita alfabética. $O$ fato de que esses mesmos traços possam ser intrinsicamente mais difíceis de observar na sua própria fala, de maneira simples e direta, também compromete a tarefa de incorporá-los a qualquer tipo de escrita. A escrita alfabética define e formata nossas intuições. Portanto, não podemos excluir a possibilidade de que fenômenos que foram agrupados convencionalmente juntos, sob a égide das definições expandidas de prosódia, foram assim agrupados, principalmente, por causa da escrita alfabética e das transcrições do IPA, e não necessariamente porque eles compartilhem propriedades essenciais na língua falada.

\subsection{Definições e Listas}

A suspeita de que o sentido linguístico extendido de prosódia não se refere na verdade a um grupo coerente de fenômenos é reforçada quando analisamos tentativas de elaborar uma definição do termo. O problema foi claramente colocado por Lehiste (1970, p. 1f):

Ainda, um certo grau de imprecisão parece caracterizar a maioria das discussões sobre traços prosódicos. Esses traços prosódicos parecem ser mais evasivos do que os traços segmentais e sua incorporação em um sistema linguístico parece às vezes tensionar os limites do que se poderia considerar como um enquadramento coerente.

Essa imprecisão se estende à definição de traços prosódicos. Na linguística americana, o termo é usado mais ou menos como um sinônimo, praticamente, de traços suprassegmentais. Traços suprassegmentais também são frequentemente listados como um conjunto que tem como elementos pitch, acento ou quantidade, ou então, são definidos como 
traços cujo domínio se estende sobre mais de um segmento (HAMP, 1957). Uma definição é sempre preferível a uma lista: no entanto, as definições referidas apresentam duas fraquezas... Se é verdade que pitch, acento e quantidade se comportam de tal forma - o que os configura à parte de traços determinantes da qualidade fonética segmental - a definição deveria ser revista.

Este não é um problema novo. Adolf Noreen, já anteriormente mencionado, introduzindo suas ideias sobre a natureza da prosódia, tem isto a nos dizer (NOREEN, 190307, p. 406, tradução do autor $\left.{ }^{8}\right)$ :

Até então o termo prosódia (prosódico/a) foi considerado num sentido limitado, designando apenas a quantidade, a intensidade e a tonalidade dos sons, ou mesmo, às vezes, apenas sua quantidade, entretanto não há nenhuma razão que justifique tal restrição.

E as observações de Lehiste são ainda bem atuais, como se pode ver em tentativas mais recentes de definir prosódia em textos técnicos. Por exemplo, a breve definição de Crystal, no glossário que faz parte da Enciclopédia Internacional de Linguística da Oxford (CRYSTAL, 1992, p. 328) diz assim:

\begin{abstract}
prosódia: variação no pitch, volume, tempo e ritmo, como se encontra em qualquer uso de língua falada (incluindo assim a noção tradicional de traços métricos da versificação); são também chamados de traços prosódicos e, em análises fonêmicas, de prosodemas. $\mathrm{Na}$ fonologia gerativa, traços prosódicos são uma das principais dimensões da classificação dos sons da fala. Na Fonologia Métrica, um dos níveis da estrutura na árvore métrica é o nível prosódico $[s i c]$. O padrão canônico de segmentos numa forma é o modelo prosódico. Na Fonologia Prosódica, a prosódia é um traço que se estende sobre um trecho do enunciado (tal como a sílaba da frase) contrastando com a noção segmental de unidades fonemáticas.
\end{abstract}

São igualmente reveladores, da dificuldade que é identificar o cerne da prosódia, os dilemas que experimetaram os autores de dicionários gerais, direcionados para um público geral. Como assinalei anteriormente, no meu prelúdio lexicográfico (ver a seção 1 deste artigo), no começo dos anos 90 os autores de dicionários que trabalhavam com línguas do oeste europeu, rapidamente perceberam a mudança de sentido dos termos prosódia e prosódico/a. Mas, basta olhar para as novas definições para evidenciarmos o quanto esses autores retrocederam ao fornecer listas ilustrativas de tópicos específicos. $\mathrm{O}$

\footnotetext{
${ }^{8}$ Retratação: eu decifro o sueco mais do que o leio. Agradeço a Merle Horne por me ajudar a localizar e dar sentido ao trabalho de Noreen.
} 
dicionário da Oxford, OED, como vimos anteriormente, define agora traços prosódicos como 'suprassegmentais', e exemplifica este termo com entoação e acento. A definição linguística de De Mauro para o italiano prosodia também faz referência aos fenômenos supressegmentais, especificando-os como 'entoação, intensidade e duração'. A segunda edição do dicionário francês Robert, assim como a primeira edição, está substancialmente relacionada à passagem da obra técnica de Marouzeau, o seu Lexique, já citado aqui anteriormente, referindo-se às 'relações dinâmicas, melódicas, quantitativas, etc.' das propriedades da linguagem.

Inclusive, se compararmos as listas apresentadas por diferentes autores de dicionários, observamos notáveis diferenças de ênfase. O dicionário espanhol de Manuel Seco et al. proporciona duas sub-divisões separadas do sentido moderno de prosodia, uma é uma tentativa de definição (em termos de traços fonéticos cujo domínio é maior do que o do fonema, como está no trecho que acabamos de citar de Lehiste), e a outra, é uma lista especificando traços da entoação e do acento. A definição de prosódia no dicionário da Academia Portuguesa é similar, mas apresenta uma lista ainda mais longa de elementos que a exemplificam: "tom, entoação, velocidade, pausa, acento, ritmo, intensidade, etc." As definições linguísticas equivalentes à do alemão Prosodie, tanto no dicionário de Wahrig quanto no Duden, diferentemente das outras línguas, enfatiza a função prosódica de fraseamento, isto é, seu papel na divisão do fluxo da fala em palavras, sintagmas e frases. Mais uma vez, no entanto, ambos dão como exemplos de prosódia: acento e entoação.

\section{ALGUMAS DISTINÇÕES QUE PODEM SER RELEVANTES PARA A DEFINIÇÃO DA PROSÓDIA}

A pluralidade de tentativas dos autores de dicionários para conseguir chegar ao significado linguístico da prosódia é uma boa amostra da confusão teórica que está por trás de sua expansão no século XX. No entanto, há uma série de maneiras de definir o seu novo sentido que de algum modo trazem uma noção coerente de prosódia, sendo que a partir de Trubetzkoy encontramos tentativas explícitas de fornecer uma base teórica sólida para distinguir características prosódicas de outros fenômenos fonéticos e fonológicos. Nesta seção propomos uma revisão dessas tentativas, seguindo uma ordem cronológica aproximada.

\subsection{Fonte versus Filtro}

Uma definição possível de prosódia e prosódico está baseada na distinção entre 'fonte' e 'filtro', conforme o sentido amplamente utilizado desses termos que se faz de acordo 
com a teoria acústica da produção da fala de Fant (1960). O sinal de fala, nesta concepção, é o resultado da passagem por uma fonte de energia acústica (mais frequentemente, a série de pulsações emanando da laringe) através de um filtro (o trato supralaríngeo que varia muito em seu formato e que, consequentemente, modifica o espectro do sinal da fonte). A ideia de definição de prosódia nessas bases foi sugerida por Trubetzkoy em seu livro Principles:

O processo de fonação da fala humana pode ser melhor ilustrado pelo seguinte esquema: alguém assobia ou canta no bocal de um tubo e abre e fecha a parte final daquele tubo com a sua mão. Três tipos de elementos podem ser claramente distinguidos, acusticamente, nesse processo: primeiro, os segmentos entre o fechamento e a abertura do orifício; segundo, os segmentos entre a abertura e o fechamento desse tubo; e, terceiro, os segmentos da melodia assobiada ou cantada no tubo. Elementos do primeiro tipo correspondem às consoantes, elementos do segundo tipo correspondem às vogais e aqueles do terceiro tipo correspondem às unidades prosódicas (1969, p. 93f).

Todavia, o próprio Trubetzkoy contradiz essa definição quando propõe, poucas páginas depois, o termo 'rítmico-melódico' como sinônimo para prosódico, sendo que em grande parte do que este autor diz sobre prosódia parece deixar claro que está preocupado, principalmente, com o pitch e a duração.

Por que isto é uma contradição? Porque propriedades rítmicas e melódicas são bastante distintas: a melodia, no sentido de contorno de pitch do sinal de saída, é de fato uma função da fonte, mas os padrões duracionais e (mais amplamente) o padrões rítmicos não. Em termos de analogia, considerando o tubo de Trubetzkoy, as propriedades rítmicas do sinal não dependem primariamente do que é cantado ou assobiado em uma extremidade do tubo (as características da fonte), mas sim dos detalhes temporais de como a outra extremidade do tubo é aberta e fechada pela mão (as modificações consonantais e vocálicas do filtro supralaríngeo). Ou seja, o ritmo percebido da fala é determinado, em grande parte, por parâmetros como a proporção de segmentos vocálicos e consonantais, a variabilidade da duração dos segmentos vocálicos e assim por diante. Essa compreensão geral do ritmo da fala foi primeiramente apresentada por Dauer (1983) e é a base de várias tentativas recentes de quantificar o ritmo de fala a partir de tais parâmetros (RAMUS et al. 1999; LOW et al. 2000; WHITE; MATTYS, 2007 e também ARVANITI, 2012). Esta definição de ritmo também está relacionada às ideias de MacNeilage (por exemplo, 1998) sobre a relação entre o ritmo da sílaba e a periodicidade física natural da abertura e 
do fechamento da mandíbula. Se quisermos considerar o ritmo como parte da prosódia, não podemos distinguir traços prosódicos de outros fenômenos fonológicos com base em uma distinção entre fonte e filtro. Ao contrário, se quisermos buscar uma definição de prosódia em termos de traços da fonte, provavelmente precisaremos excluir o ritmo.

\subsection{Não verbal versus Verbal}

Outra forma possível de distinguir o prosódico de outros traços é relacioná-lo à diferença entre o conteúdo proposicional expresso em palavras e tudo o mais que é veículado pela fala. Como observado na seção 2.2, essa compreensão muito mais ampla do quê a prosódia de fato envolve é especialmente comum tanto em psicologia e psiquiatria, na terapia da fala, quanto no campo da tecnologia da fala. Certamente há uma distinção válida a ser traçada a partir dessas linhas, ${ }^{9}$ embora eu, particularmente, prefira o termo paralinguístico para a maior parte do que é incluído na prosódia quando é definido dessa maneira. Parece haver aspectos universais do modo como algumas características dos falantes individuais são transmitidas pela fala, sendo as mais notáveis as diferenças biologicamente motivadas entre vozes masculinas e femininas adultas. Manifestações de estado emocional, expressas informalmente por expressões como 'elevar o tom de voz' ou 'gritar com alguém', provavelmente também têm uma base biológica e podem ser incluídas aqui, embora sejam bem conhecidas as diferenças culturais em relação à aceitação social de demonstrar essas manifestações. A produção e a percepção desses traços podem ser prejudicadas, em grande parte ou mesmo totalmente, por causa de danos cerebrais ou distúrbios psicológicos, independentemente de que isso afete a linguagem. Parece claro que o foco clínico/psicológico nos aspectos não-verbais da comunicação falada é baseado em uma distinção legítima.

No entanto, identificando esses aspectos com 'prosódia', temos de lidar com uma grande contradição: por um lado, esperamos que a prosódia esteja relacionada à expressão de emoção e atitude, mas por outro lado, assumimos que tudo o que não é segmental é prosódico. O problema mais óbvio é que alguns traços não-segmentais, como o tom lexical, manifestamente contribuem para o conteúdo proposicional, e não necessariamente estão relacionadas à expressão da emoção. Mesmo em línguas não-tonais, há casos como o par de frases mostrado em inglês por Rooth (1985), no qual a colocação do acento na frase cria dois significados distintos com diferentes condições de verdade:

\footnotetext{
9 Esse tópico é desenvolvido no Capítulo 4, Modualções, sub-dividido em quatro partes: (1) Indexical and propositional content; (2) Gradience; (3) Paralanguage ("Gradience in paralanguage"; "Cultural and contextual interpretation of paralinguistic signals”); (4) Implications for phonology ('Segment-level effects of paralinguistic cues", "Sociophonetic variation", "Categorical modulation:ablaut and ideophones"), em Ladd (2014).
} 
(1) (i) John only introduced Bill to SUE.

[João apresentou o José apenas para a MARIA.]

(2) (ii) John only introduced BILL to Sue.

[João apresentou apenas o JOSÉ para a Maria.]

De modo geral, há muitas questões de pesquisa empírica sobre a comunicação não verbal em si, razão pela qual psiquiatras, psicólogos sociais e inclusive os que trabalham com tecnologia da fala não precisam se preocupar ou sequer pensar nessa contradição teórica. Para os linguistas, entretanto, resolver essa contradição tem uma prioridade muito maior. Uma via para resolver tal questão, por exemplo, orientou pesquisadores na busca de explicações para a entoação relacionando-a à emoção (por exemplo, Bolinger 1972, 1986). Na minha opinião, estas tentativas são geralmente bastante implausíveis e (o que é pior) não testáveis (LADD, 1987), mas podem, ainda assim, ser válidas. Entretanto, ignorar simplesmente o problema do tom lexical como um todo, relegando-o a algo fundamentalmente exótico e misterioso (por exemplo, MARTINET, 1980, 83ff.) - me parece uma visão inapropriada e etnocêntrica para um campo que procura entender tanto a unidade quanto a diversidade da linguagem.

\subsection{Suprassegmental versus Segmental}

O sucesso das representações segmentais da fala na escrita alfabética em geral, e na transcrição do IPA em particular, torna tentador ver qualquer coisa que não possa ser escrita em termos de segmentos como parte de uma classe distinta de fenômenos. Como já vimos, essa base implícita para definir 'prosódia' parece ter se desenvolvido, de forma independente, tanto no mundo greco-romano clássico quanto na linguística do século XX. A base teórica da distinção, é claro, nunca foi explicitamente ligada à representação alfabética, mas o próprio termo 'suprassegmental' - adotado no início da década de 1940, por Trager e Bloch (1941, p. 224) e Hockett (1942, p. 8), por exemplo - sugere que esses traços estão de algum modo 'acima' da cadeia de segmentos e, portanto, pressupõem uma idealização fonética segmental da corrente da fala. ${ }^{10}$

As duas noções que figuram majoritariamente na definição de 'suprassegmental' são as de que os traços suprassegmentais (a) ocorrem simultaneamente com segmentos e (b) se estendem por um domínio mais amplo do que um único segmento. A simultanei-

${ }^{10}$ Para aprofundamento da questão, ler Capítulo 2, Fonética na Fonologia, Seção 2.3.4, "Segmental, suprasegmental, autosegmental”, em Ladd (2014). 
dade parece ser uma parte importante do que levou à identificação do tom, do acento e da quantidade (as “características rítmico-melódicas" de Trubetzkoy, por exemplo) como componentes essenciais da prosódia. $\mathrm{O}$ segmento é definido por um conjunto limitado de propriedades fonéticas - modo, ponto, vozeamento e assim por diante - e quaisquer propriedades fonéticas remanescentes devem ser vistas como algo separado, ocorrendo simultaneamente com o segmento, mas não como parte daquilo que o define. Se houvesse um princípio básico para determinar quais propriedades fonéticas são segmentais, então essa definição de suprassegmental seria justificável. Porém, na medida em que as definições de propriedades segmentais são baseadas em suposições alfabéticas eurocêntricas, a definição se torna bastante circular. Há muitas maneiras, por exemplo, em que o tom e o vozeamento - ou talvez seja mais correto afirmar, a frequência fundamental e o VOT (voice onset time) - interagem na identificação de distinções 'segmentais' ${ }^{11}$. Um caso desse tipo, atualmente já bastante estudado, é o que envolve os três tipos de contraste laríngeo das consonantes oclusivas coreanas (por exemplo, SILVA, 2006; KIRBY, 2013).

Quanto à ideia de que os traços suprassegmentais têm intrinsecamente maior extensão temporal (ou que, mais abstratamente, se aplicam a domínios maiores na fonologia), parece ser um pouco menos circular, na medida em que depende apenas da existência de alguma representação fonética segmentada, e não de um conjunto específico de propriedades 'segmentais'. Aqui também, no entanto, existem problemas evidentes. Um desses problemas é que, pelo menos, alguns dos traços que são comumente considerados como suprassegmentais não necessariamente se estendem sobre múltiplos segmentos. Isso é verdade quase que por definição para a distinção de quantidade, que envolve principalmente propriedades fonológicas de segmentos individuais. $\mathrm{O}$ tom lexical também pode representar problemas, pois, em uma sílaba formada por uma consoante não vozeada, uma vogal e um tom, o tom se aplica exatamente a apenas um segmento. Isso torna mais difícil justificar a separação do tom das outras propriedades fonéticas do segmento vocálico. Esse problema já tinha sido reconhecido na década de 1940 por Zellig Harris, quem chegou a comentar sobre a arbitrariedade de tratar o tom como um componente separado de uma vogal e sugeriu que 'poderíamos afirmar que uma língua não tem, digamos, 5 vogais e 3 tons, mas 15 fonemas vocálicos' (1944, p. 200 [1966, p. 135; 1972, p. 129]).

O problema oposto também é bastante comum e, de certo modo, é mais fundamental: traços fonéticos que não os rítmico-melódicos frequentemente se estendem por uma sequência de múltiplos segmentos. Se decidirmos tratar o pitch de maneira diferente,

${ }_{11}$ Para aprofundar a discussão, ler Capítulo 2, Fonética na Fonologia, Seção 2.3.2, "Systematic phonetics as interface representation", em Ladd (2014). 
considerando que ele se aplica a mais de um segmento fonético em sequência, a lógica sugere que o mesmo tratamento deve ser aplicado a traços como o ponto de articulação ou o vozeamento ou a nasalidade quando estes se aplicarem a dois ou três segmentos sucessivos. Por exemplo, uma vez que agrupamentos de obstruentes em inglês, quando em posição de coda silábica, invariavelmente concordam em vozeamento (por exemplo, 'gatos' cats [kæts] tem um agrupamento final não vozeado vs. 'grosseiros' cads [kædz] que tem uma agrupamento final vozeado, entretanto * [kætz $]$ e * [kæds] são impossíveis), parece justificável tratar a sonoridade como um traço suprassegmental que abrange toda a coda silábica. Considerações desse tipo estão na raiz de algumas das primeiras discussões de Hockett sobre traços fonéticos (por exemplo, HOCKETT, 1942) e da exploração muito mais aprofundada de Zellig Harris sobre a noção de 'componentes longos' na fonologia (HARRIS, 1944). Contudo, a única escola de pensamento que levou a sério tais assuntos foi a Fonologia prosódica firthiana. Como vimos anteriormente na seção 2.2, a teoria de Firth não atribui nenhum status especial aos traços rítmico-melódicos, e insiste em definir 'prosódias' em termos específicos aos de uma língua em particular. Os traços que caracterizam regularmente domínios maiores do que o de um único segmento foram tratados como prosódias desses domínios específicos (por exemplo, 'prosódias da sílaba'). Assim sendo, considerável atenção teórica foi dada à definição desses tipos de estruturas fonológicas que constituem os domínios sobre os quais as prosódias podem ser aplicadas. A maioria dos outros fonólogos teóricos reconheceu essa confusão lógica, mas nunca permitiu que se ignorasse a noção intuitiva de que há uma diferença entre (digamos) o tom e o ponto da articulação. À exceção da linguística firthiana, a suposição de que o tom, o acento e a quantidade fazem parte de um conjunto coerente derrotou as outras considerações, sendo que as propostas dos chamados componentes longos de Harris realizaram, desde então, muito pouco progresso teórico.

\subsection{Prosódico versus Inerente}

Talvez a tentativa mais séria e credível e que tenha fornecido a motivação para tratar os traços rítmico-melódicos como uma classe única e coerente, mais do que como uma gama de fenômenos fonológicos, tenha sido feita por Roman Jakobson. A ideia básica é claramente declarada por Jakobson, Fant e Halle (1952; obra que daqui pra frente será referida como JFH) no contexto de sua elaborada teoria sobre traços distintivos, que implica uma distinção fundamental entre traços 'inerentes' e traços 'prosódicos'. Os traços inerentes são os traços familiares que distinguem um segmento de outro - consonantal, 
vocálico, estridente, grave e assim por diante - enquanto os traços prosódicos são aparentemente limitados àqueles relativos a pitch, acento, quantidade e talvez silabicidade (a apresentação feita por JFH é breve e pouco clara sobre este último ponto). A propriedade definidora dos dois tipos de traços, de acordo com JFH (1952, p. 13), é que os traços inerentes podem ser identificados em uma única porção de tempo no sinal 'sem qualquer referência à sequência', enquanto que os traços prosódicos 'só podem ser definidos com referência a uma série temporal'. Dessa forma, uma vogal alta ou uma oclusiva labial podem ser reconhecidas como tais sem referência a qualquer outra parte do sinal de fala, mas uma sílaba tônica é tônica apenas por comparação com uma sílaba átona, e um tom alto é considerado alto somente em comparação com um tom baixo. Jakobson parece ter sustentado essa ideia ao longo de sua vida; essa noção foi mais elaborada posteriormente em Jakobson e Waugh (1979), obra na qual (como observado na seção 2.2) a afirmação original da ideia é atribuída a Noreen $(1903-07)^{12}$. Essa mesma abordagem, que define os fenômenos suprassegmentais como uma classe coerente, foi adotada por Lehiste em seu livro Suprasegmentals (1970, p. 35f).

No entanto, essa definição é muito menos bem-sucedida do que quando aparece pela primeira vez. Não é difícil pensar em traços 'inerentes' que também requerem referência a uma série temporal: sabe-se, por exemplo, que as pistas para o ponto de articulação das oclusivas orais e nasais residem principalmente nas vogais adjacentes, e que, ainda, a distinção entre oclusivas aspiradas e não aspiradas, vozeadas ou não, é, em parte, decorrente do que acontece entre o momento do fechamento da oclusão e o início da vogal seguinte. Inclusive a percepção correta da qualidade das vogais depende, de certo modo, de se ter uma concepção do espaço vocálico do locutor, que é derivado em parte de outras vogais no mesmo enunciado (LADEFOGED; BROADBENT, 1957; NEAREY, 1989). Ao contrário, a ideia de que os traços prosódicos invariavelmente exigem uma comparação interna é também difícil de sustentar, especialmente para o pitch: é perfeitamente possível ter frases formadas, em muitas línguas africanas por exemplo, somente com tons silábicos altos, que podem ser identificados como tais mesmo sem a presença de outros tons para uma comparação explícita. Eu discuti o problema da normalização do pitch mais aprofundadamente em outro texto meu (LADD 2008a, p. 188-210 [1996, p. 252-269]), defendendo uma noção fonética do 'espaço tonal' como inteiramente análoga

\footnotetext{
${ }^{12}$ O que Noreen realmente diz (1903-07, p. 406) é que traços prosódicos são 'aqueles que emergem quando comparamos os sons uns com os outros na fala conectada' [de som hos ljuden i sammanhangande tal framtrada vid deras inbordes jamforelse]. O termo que eu traduzi aqui como 'traços' é egenskaper, que é um cognato direto do termo cunhado em alemão Eigenschaften - isto é, traços como 'propriedades' ou 'atributos'. Novamente, obrigada a Merle Horne pela ajuda de leitura no que diz respeito ao texto original de Noreen.
} 
à do 'espaço vocálico'. A única diferença importante entre pitch e timbre da vogal nesse aspecto é que o primeiro pode variar manifestamente de um falante para outro, ou de um evento para outro. Em nenhum dos dois casos, há qualquer invariância acústica entre os falantes: é sempre necessária alguma calibragem ou ajuste em função do falante. Pode ser que exista uma justificativa para uma idealização tal que considere alguns traços como imediatos, e outros como intrinsecamente baseados em uma comparação entre dois pontos no tempo. Entretanto, é difícil basear essa idealização em evidências experimentais a partir da percepção da fala e não é uma tarefa fácil ou inequívoca chegar a distinguir, nitidamente, pitch, acento e quantidade de todo o resto, no contínuo da fala.

\subsection{Sintagmático versus Paradigmático}

Apesar das objeções que acabamos de resumir, a ideia de Jakobson (ou talvez seja a de Noreen) consegue captar de perto a essência de uma importante distinção fonológica. Existe realmente uma divisão fundamental entre traços sintagmáticos - aqueles que intrinsecamente implicam uma comparação entre um elemento e outro na cadeia fonológica - e traços paradigmáticos - aqueles que envolvem a escolha de um conjunto de alternativas específicas da linguagem em um determinado ponto da estrutura. No entanto, a versão jakobsoniana dessa ideia é prejudicada por dois equívocos inter-relacionados. Em primeiro lugar, porque ele assume uma percepção básica e tenta torná-la compatível com uma ideia preconcebida de quais traços fonológicos são prosódicos, ou seja, os já mencionados traços 'rítmico-melódicos' de Trubetzkoy. Em segundo lugar, porque sua noção de comparação sintagmática está mais ancorada no tempo real (e possivelmente na percepção da fala) do que em estruturas linguísticas abstratas. Ele não reconhece que existem diferenças significativas entre traços amplamente 'melódicos' (que são funcionais e estruturalmente bastante similares aos traços segmentais) e traços amplamente 'rítmicos' (que envolvem, efetivamente, a comparação sintagmática como parte de sua essência fonológica).

A ideia de que as distinções do acento são intrinsecamente sintagmáticas foi uma grande contribuição da tese de doutoramento de Mark Liberman (LIBERMAN, 1975 [1979]; LIBERMAN; PRINCE, 1977). De acordo com Liberman, qualquer par de nodos irmãos em uma estrutura hierárquica de constituintes fonológicos deve estar em uma relação prosódica de proeminência na qual um deles está subordinado ao outro. Por exemplo, em um sintagma simples como five pounds [cinco libras], existem duas relações possíveis, fraca-forte e forte-fraca, que podem ser diagramadas da seguinte forma: 
$(2)$

(a)

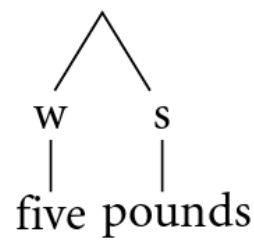

(b)

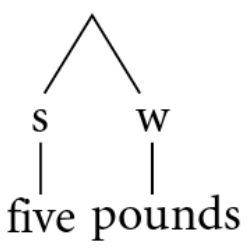

Tais relações de proeminência aplicam-se a todos os níveis da hierarquia estrutural, como no sintagma seven dollars [sete dólares]:

(3)

(a)

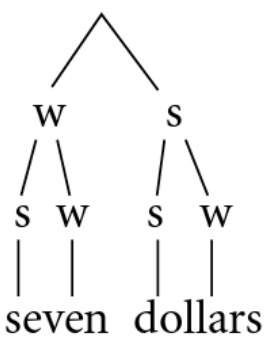

(b)

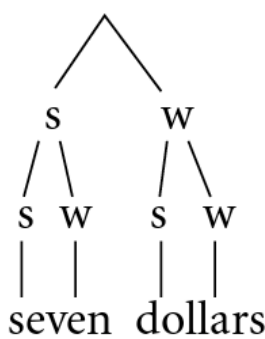

As versões (a) são pragmaticamente apropriadas em uma ampla variedade de circunstâncias, enquanto que as versões (b), informalmente falando, têm 'acento contrastivo' no número. $\mathrm{O}$ quadro completo apresentado na análise de Liberman implica também elementos paradigmáticos locais - notavelmente análogos ao que hoje é normalmente chamado de 'pitch accents', e um traço [acento] que é relevante para as distinções de redução vocálica, nas sílabas inacentuadas do inglês. No cerne de sua proposta, se encontra a ideia de que a essência fonológica do acento é a de uma proeminência relativa dentro de uma estrutura hierárquica. Segundo Liberman e Prince (1977, p. 333), 'a proeminência relativa é definida entre constituintes fonológicos, e não entre segmentos individuais'.

A plausibilidade dessa ideia deixa claro - por comparação - que não existe nada semelhante em termos lexicais ou gramaticais. Há uma clara diferença de significado em chinês entre tāng ('sopa') e táng ('açúcar'), mas essa distinção não depende de forma alguma da relação fonológica entre uma palavra e outra em uma dada frase. As duas palavras - e, em última instância, os dois tons fonemáticos - são membros categoricamente distintos de um conjunto paradigmático, exatamente da mesma forma como se dá a diferença entre táng ('açúcar') e tóng ('latão'). Se essa comparação entre dois pontos em tempo 
real está envolvida na percepção de tais distinções, ou não, - que é o que foi enfatizado pela distinção do Jakobson, Fant e Halle (1952) entre traços 'prosódicos' e 'inerentes' - é uma questão estruturalmente irrelevante. Em vez disso, a distinção entre sintagmático e paradigmático sugere que os traços 'rítmico-melódicos' de Trubetzkoy em si não formam uma classe natural de fenômenos.

\subsection{Periodicidade mais lenta versus Periodicidade mais rápida}

Finalmente, novas evidências de uma divisão muito diferente apontam para a possibilidade de que uma distinção entre segmental e suprassegmental possa ser incorporada à maneira como processamos a fala no nível neural. Esta divisão propõe (por exemplo, POEPPEL, 2003, GIRAUD et al., 2007, GIRAUD, POEPPEL, 2012) que as oscilações neurais ('ondas cerebrais') com frequências características diferentes estimulam, naturalmente, a atenção para aspectos do sinal de fala com diferentes características temporais. Nas palavras de Giraud e Poeppel, há "uma relação de princípio entre as escalas de tempo presentes na fala e as constantes de tempo subjacentes às oscilações neuronais que são tanto um reflexo quanto os meios pelos quais o cérebro converte os ritmos de fala em segmentos linguísticos" (2012, p. 511). Especificamente, as ondas gama, com uma frequência típica de $25-35 \mathrm{~Hz}$, facilitariam o processamento de segmentos e alguns eventos acústicos sub-segmentais, como as fases de oclusão e relaxamento de uma consoante oclusiva; ondas teta, com uma frequência típica de 4-8 Hz, focalizariam as propriedades globais das sílabas em sequência; e as ondas delta, com uma frequência típica de 1-3 Hz, seriam relevantes para detectar as propriedades dos sintagmas. Ou seja, pode haver uma base biológica para o arranjo hierárquico dos domínios fonológicos e para a visão de que certos tipos de propriedades fonéticas pertencem intrinsecamente a domínios de tamanhos diferentes. Se isso for verdade, temos um argumento para o tratamento da "prosódia” não simplesmente como um artefato da escrita alfabética, mas como um fenômeno que pode ser distinguido da fonologia segmental por uma base independente.

\section{ENTÃO, O QUE É PROSÓDIA?}

Uma conclusão justificada, que decorre desta lista de definições possíveis, seria a de que o sentido corrente de prosódia é realmente incoerente. Nesse caso, a expansão do termo entre os antigos gramáticos e na linguística moderna é essencialmente um artefato da escrita alfabética: a prosódia é um pacote de elementos difíceis de escrever com um série sequencial de símbolos. Entretanto, os fenômenos desse elementos congregados pelo 
pacote da prosódia parecem dividir-se em dois grandes grupos. Um deles diz respeito às propriedades fonéticas que são frequentemente consideradas em paralelo à sequência segmental - elementos como o pitch são bastante independentes da sequência segmental articulatória - bem como elementos que pedem extensões da fala mais longas do que as dos segmentos individuais. O outro conjunto se agrupa no entorno da estrutura hierárquica e das relações sintagmáticas. As oposições discutidas na seção anterior podem ser divididas em dois grupos, de acordo com estas duas linhas. Se por um lado as oposições: fonte vs. filtro, não-verbal vs. verbal, suprassegmental vs. segmental e periodicidade mais lenta vs. periodicidade mais rápida, são oposições que dizem respeito a correntes fonéticas paralelas e a propriedades tais como a extensão de domínio do conjunto segmental, por outro lado, a distinção sintagmática/paradigmática (e sua precursora prosódico vs. inerente) envolve a estrutura hierárquica do conjunto mesmo.

É bastante tentador sugerir que estes são os dois conjuntos de fenômenos que começaram a ser investigados nos anos 70 sob as rubricas "fonologia autossegmental" e "fonologia métrica". O termo "prosódia", considerado como uma extensão coerente dessas duas tradições de pesquisa, pode ser descrito no sentido moderno como tendo duas grandes vertentes, mais do que como um repertório de tópicos independentes e não relacionados. Infelizmente, a fonologia autossegmental está enfrentando tempos difíceis, e os tópicos de maior interesse para a fonologia autossegmental nos seus dias áureos (sândi tonal e harmonia vocálica) parecem muito diferentes do que hoje se poderia chamar como a extensão de domínio de propriedades dos enunciados tais como extensão do pitch e qualidade vocal. Provavelmente, o único elemento que esses fenômenos têm em comum é o fato de que não se acomodam facilmente numa idealização da fala segmental. Já a fonologia métrica, parece mais promissora, há uma vasta variedade de trabalhos sobre a organização hierárquica dos enunciados e sobre o que passou a ser conhecido como "a hierarquia prosódica” (por exemplo, HAYES, 1989; JUN 1998; FROTA, 2000). Grande parte desses trabalhos derivam diretamente do programa de pesquisa inaugurado pela tese de Liberman e foram além do acento e da entoação, considerando outras manifestações da estrutura hierárquica, tais como sândi em função do contexto segmental, ou seja da natureza do segmento (por exemplo, NESPOR, VOGEL, 1986) e detalhes temporais da fala tais como o "alongamento final" (por exemplo, TURK; SHATTUCK-HUFNAGEL, 2007) e "intensificação do domínio inicial" (por exemplo, CHO; KEATING, 2001). Entretanto, para alguns pesquisadores, a "fonologia métrica" e a "fonologia prosódica" são diferentes quadros teóricos, com a notável exceção do trabalho de Mary Beckman 
(por exemplo, BECKMAN, 1986, capítulo 3; PIERREHUMBERT; BECKMAN, 1988, capítulo 6; BECKMAN, 1996). Houve muito pouco interesse em procurar uniformizar as teorias sobre a estrutura sintagmática na fonologia - levando a sério o que Beckman (1996, p. 19) diz e considerando: "a noção de prosódia como a estrutura organizacional pura”.

A longo prazo pode ser que se que ocorra uma integração teórica dos aspectos amplamente "autossegmentais" e dos aspectos amplamente "métricos" da fala, mas essa integração está ainda muito longe do que é a realidade atual do nosso conhecimento. Minhas declarações mais recentes assinalam os pontos convergentes das duas áreas e como ambas poderiam se combinar perfeitamente mas mostram também quanto caminho ainda temos pela frente nesse sentido. Em Ladd (2008a, capítulo 8), eu defendo a ideia de que precisamos incorporar algumas noções de estrutura hierárquica nas nossas análises de fonologia entonacional. E ainda, neste mesmo ano em Himmelmann e Ladd (2008), eu também apresento algumas ideias sobre fenômenos acentuais que são, ao meu ver, diferentes de outras propriedades "prosódicas". Eu estou, particularmente, de acordo com Beckman quanto à necessidade de uma boa teoria geral da estrutura fonológica sintagmática, e com a memorável frase de Pierrehumbert e Beckman (1988, p. 160): "nós falamos árvores, não cadeias ou sequências". Mas até o momento é difícil imaginar como tal teoria poderia se útil para a compreensão, digamos da extensão global do pitch, ou de detalhamentos fonéticos específicos das línguas nos movimentos entonacionais do pitch.

Quando eu estava escrevendo a primeira edição do Intonational Phonology (LADD, 1996), eu tentei encontrar um único termo para descrever a abordagem da estrutura entonacional, com base em Liberman (1975), Bruce (1977) e Pierrehumbert (1980). Na época, eu escrevi para uma série de colegas ativos e produtivos na área e ofereci uma recompensa para quem pudesse propor um termo melhor do que "autossegmental e métrica”, termo que eu estava usando como um substituto eventual e que parecia ser bastante exato mas que me pareceu desesperadoramente confuso. Ninguém conseguiu achar um termo melhor, e o termo "autossegmental e métrica” emplacou, embora seja usado atualmente na sua forma abreviada "AM" (do inglês autosegmental-metrical). A impossibilidade de chegar a um nome unificador parece ser sintomática do fato de que os dois conjuntos de fenômenos são bastante distintos. É difícil predizer se pesquisas futuras mostrarão vias para uma genuína integração desses dois grupos, ou se confirmarão que estamos efetivamente diante de fenômenos bem distintos que não devem ser amalgamados sob um único título ou etiqueta: "prosódia”. Nesse meio tempo, a palavra em si "prosódia”, parece que veio pra ficar. 


\section{APÊNDICES DE DEFINIÇÕES}

O material em apêndice deste estudo está dividido em duas partes: (1) uma revisão panorâmica dos termos prosódia e prosódico/a em dicionários em inglês e em outras línguas europeias e (2) os resultados da busca no Google Scholar ${ }^{\mathrm{TN}}$ de títulos contendo os adjetivos prosódia e prosódico/a considerando períodos de cinco anos (antes dos anos 70, de 1971 a 1975, de 1976 a 1980, de 1981 a 1985, de 1986 a 1990, de 1991 a 1995, de 1996 a 2000 e de 2001 a 2005).

\subsection{Definições de prosódia ou prosódico/a em dicionários}

Nos dicionários impressos para um público geral de francês, alemão e italiano, publicados nos anos 70 e 80, as palavras correspondentes a prosody e prosodic, em inglês, são definidas de forma equivalente à primeira definição original no dicionário de inglês da Oxford (OED), ou seja, o sentido está relacionado à versificação e à métrica. No dicionário alemão Wahring (publicado pela primeira vez em 1968 e revisado em 1979), a configuração musical do texto é mencionada a esse respeito. Alguns dicionários italianos também fazem referência ao sentido clássico da palavra grega acentos. Em espanhol e português, o sentido tradicional parece estar bem mais próximo à segunda acepção do $\mathrm{OED}$, relacionado à pronúncia correta, mas o sentido linguístico moderno encontra-se igualmente ausente nesses dicionários. No que diz respeito ao sentido firthiano, não poderíamos esperar, naturalmente, que aparecesse nos dicionários de outras línguas, uma vez que é um sentido restrito veiculado por um pequeno grupo de estudiosos acadêmicos que escrevem em inglês.

Eu só encontrei duas indicações claras do sentido linguístico moderno nesses dicionários antes da metade dos anos 90. Uma é no dicionário francês, Robert, que cita o dicionário de Marouzeau, dicionário técnico previamente citado neste artigo. Cabe assinalar que a citação diz respeito apenas ao termo prosodique, e não ao termo prosodie:

prosodique: ... Phonét. Caractéristiques prosodiques d'une langue: "Les éléments phoniques (dynamique, mélodique, quantitatif, etc.) qui caractérisent telle ou telle tranche de la chaîne parlée, par ex. dans le mot, la syllabe" (Marouzeau).

[prosódico:... Fonét. Características prosódicas de uma língua: "Os elementos fônicos (dinâmico, melódico, quantitativo, etc.) que caracterizam um determinado trecho no contínuo da fala, por exemplo, na palavra, a sílaba" (Marouzeau).] 
A outra está no dicionário italiano UTET, uma imensa obra em muitos volumes, editada por Battaglia e Barberi Squarotti, cuja publicação começa em 1961, mas o volume que contém a definição de prosódia só aparece em 1988. As duas primeiras definições se referem ao uso clássico e poético, mas a terceira diz:

Fonol. Nella linguistica moderna, l'insieme dei caratteri fonici (dinamici, melodici, quantitativi) che sono peculiari di una determinata sezione del discorso.

[Fonol. Na linguística moderna, o conjunto de propriedades (dinâmica, melódica, quantitativa) que são características de uma determinada parte do discurso.]

A formulação do texto sugere, muito claramente, que esta definição também está baseada na de Marouzeau.

\subsection{Busca dos termos em inglês prosody ou prosodic por títulos de trabalhos científicos em Google Scholar}

Em abril de 2011, eu realizei uma busca através da ferramenta Google Scholar procurando títulos de publicações em inglês que tivessem o substantivo prosody ou o adjetivo prosodic. Eu examinei as mudanças de frequência considerando o número de publicações com estas palavras no título. A fim de ter uma impressão mais nítida do contexto crescente entre o material publicado em linguística e disponível pelas ferramentas de busca do servidor Google, eu também procurei títulos que contivessem uma amostra de outros termos inequivocamente linguísticos (por exemplo, pronominal, fricative, ergative e diglossia, mas não morphology, segmental, labial ou pragmatic, que também são usados em outras áreas do conhecimento).

É importante considerar que não procurei corrigir entradas duplicadas, embora algumas poucas entradas espúrias tenham sido manualmente descartadas. Os resultados são mostrados nos gráficos a seguir. Todos os gráficos mostram oito intervalos de tempo, começando com todos os títulos publicados em 1970 ou antes, sendo que os intervalos continuam a partir de então de cinco em cinco anos: 1971-75, 1976-80 e assim até 200105 .

Na maioria dos casos, há mais títulos no primeiro período do que no segundo, mas isso se explica apenas pelo fato de que o primeiro período inclui tudo o que está registrado online no Google antes de 1970, incluindo este ano. O aumento global de 1971-75 a 200105 é genuíno, refletindo tanto o crescimento do volume de publicações acadêmicas quanto o aumento da sua disponibilidade e rápido acesso na internet, enquanto material online. 


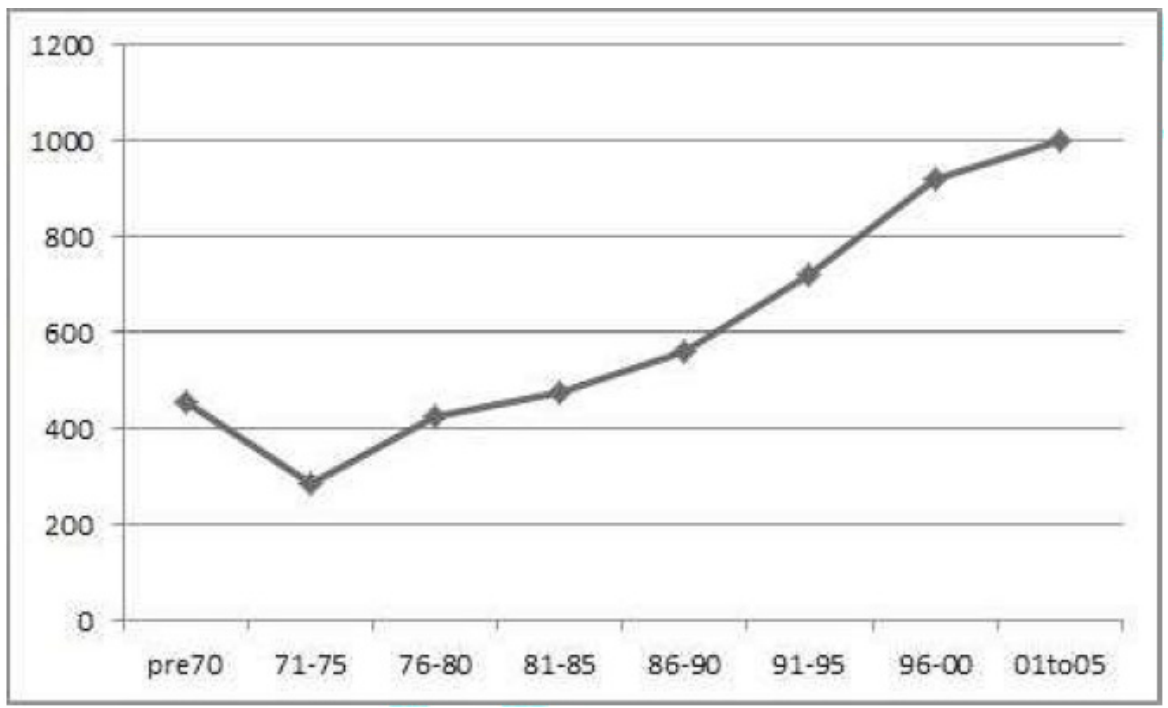

Figura 1. Média de trabalhos encontrados no Google Scholar com termos linguísticos no título em inglês. Período 1 = prévio ou anterior aos anos 70; e em seguida com 5 anos de intervalo (197175, 1976-1980, etc. até 2001-2005). Os termos incluídos foram: pronominal, interrogative, accentual, intonation, lexical, syntactic, phonology, fricative(s), vowel, ergative, diglossia, deixis e diphthongs(s).

A média de aumento em número de títulos linguísticos entre 1971-75 e 2001-2005 é de aproximadamente $350 \%$ - ou seja, há aproximadamente três vezes e meio a mais de títulos linguísticos registrados no Google Scholar no período de 2001-05 do que no período de 1971-75. Observamos um aumento de 200\% para o termo diglossia e ergative, bem como um aumento de quase $500 \%$ para os termos pronominal e deixis, sendo que o termo lexical teve um crescimento extraordinário de quase $1000 \%$. Os resultados globais são mostrados no gráfico da Figura 1. Uma escolha diferente dos termos teria sem dúvida levado a resultados diferentes em seu detalhamento, mas nos parece razoável sugerir que houve um aumento de três a quatro vezes mais publicações em linguística nos últimos 40 anos, ou nas últimas quatro décadas.

Comparado com esse crescimento global do conjunto de publicações , o aumento dos títulos contendo "prosody" e "prosodic" foi muito maior nesse contexto, chegando também aos $1000 \%$. Ou seja, temos agora, dez vezes mais publicações em prosódia do que há 40 anos. Este aumento extraordinário pode ser visto na Figura 2, que mostra um aumento global dos termos prosody e prosodic, sem considerar o sentido nos quais estes dois termos são utilizados. 


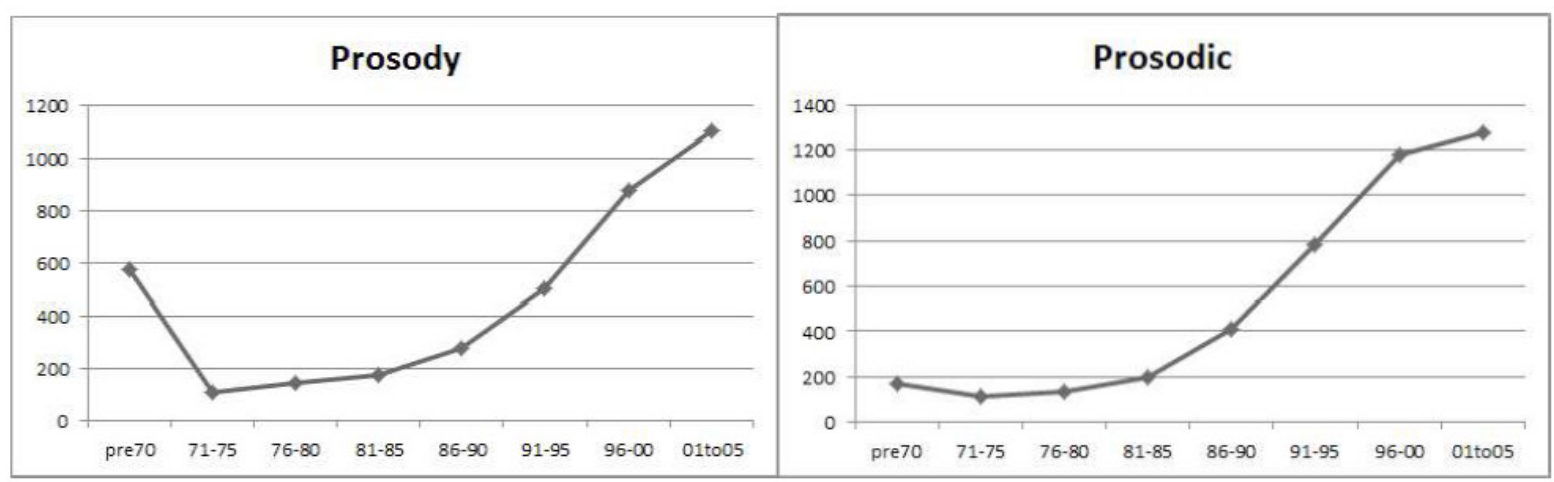

Figura 2. Visualizações de trabalhos no Google Scholar com termos prosody, prosodic no título em inglês. Como na Figura 1, o período 1 = prévio ou anterior aos anos 70; e em seguida com 5 anos de intervalo (1971-75, 1976-1980, etc. até 2001-2005).

Para ter uma ideia da dimensão dessa mudança de sentido das palavras, eu fiz uma classificação aproximativa a partir das duas formas de repertoriar os títulos que continham cada palavra em inglês, considerando, por um lado, se tinham sido tratadas dentro do campo da poesia e da métrica ou, por outro lado, se tinham sido tratadas dentro de campos relacionados à linguística ou à psicologia, incluindo neste segundo caso o sentido linguístico usual de prosódia (seja lá qual for ou se considere que seja esse sentido). A classificação foi feita exclusivamente considerando os títulos e as breves resenhas que aparecem nas páginas dos resultados de buscas em Google Scholar, e portanto podem conter alguma classificação incorreta, mais uma vez não me dei ao trabalho de procurar corrigir entradas duplicadas. Dada esta metodologia, os números devem ser considerados apenas como estimativas, mas mesmo assim conseguem dar-nos uma imagem bastante acertada e uma representação convincente da mudança de sentido desses termos.

As Figuras 3 e 4 mostram que prosody passou por uma mudança visível do sentido poético ao sentido não-poético nos anos 70, enquanto que o adjetivo prosodic parece nunca ter sido muito usado no sentido poético, pelo menos não nos títulos. Para as duas formas, tanto o substantivo quanto os adjetivos, pode-se observar que o crescimento de 1000\% que mostra a Figura 2 se deve inteiramente ao sentido não-poético do termo. A Figura 3 dá os números absolutos das publicações, enquanto a Figura 4 mostra os mesmos dados, mas apresentados na forma de proporção com relação ao número total de publicações. 


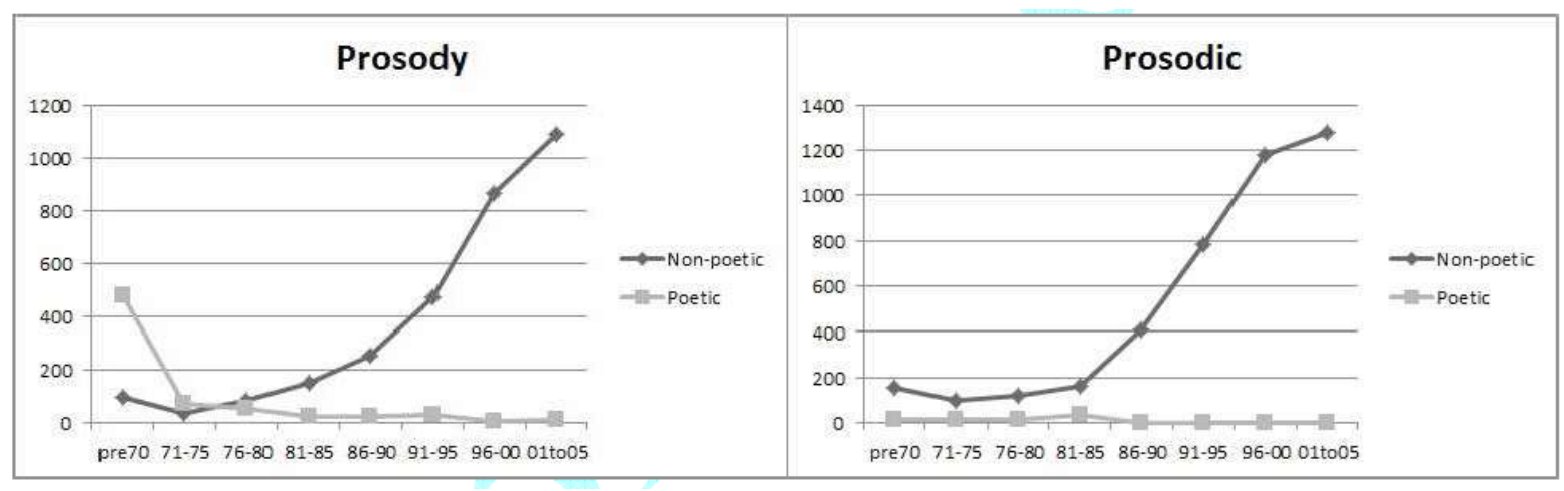

Figura 3. Visualizações estimadas de trabalhos no Google Scholar com sentido poético (Poetic) e nãa-poético (Non-poetic) para os termos prosody, prosodic no título em inglês. Como na Figura 1, o período 1 = prévio ou anterior aos anos 70; e em seguida com 5 anos de intervalo (1971-75, 1976-1980, etc. até 2001-2005).

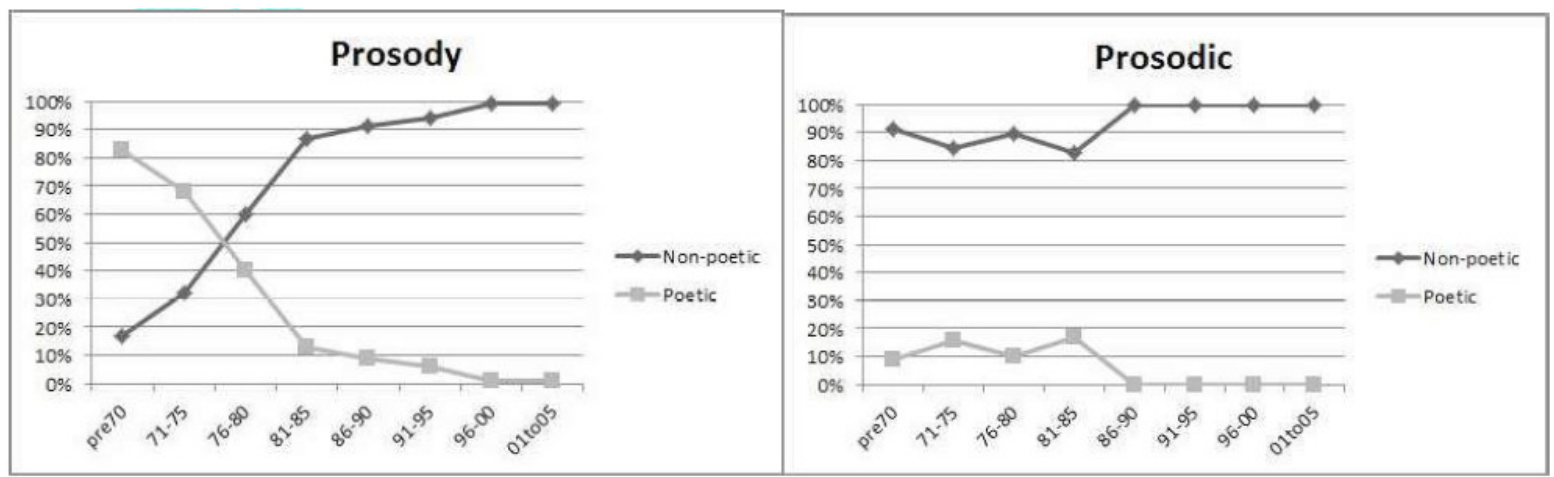

Figura 4. Visualizações estimadas de trabalhos no Google Scholar com sentido poético (Poetic) e não-poético (Non-poetic) os termos prosody, prosodic no título em inglês. Os valores foram expressos em termos percentuais, considerando o número total de visualizações dos dois termos. Como na Figura 1, o período 1 = prévio ou anterior aos anos 70; e em seguida com 5 anos de intervalo (1971-75, 1976-1980, etc. até 2001-2005).

Finalmente, eu quis empreender uma classificação ainda mais acurada para os mesmos dados, classificando os usos não-poéticos em usos congruentes com a teoria fonológica de Firth e os não congruentes com os usos de Firth, e ainda classificando de forma bastante aproximativa, os usos não congruentes com a teoria de Firth em usos pertencentes tanto aos campos da linguística (incluindo os campos de tecnologia da fala) quanto aos da psiquiatria ou psicologia clínica. Os sentidos congruentes com a teoria de Firth praticamente desaparecem dos títulos depois de 1985, seja na sua forma de substantivo ou adjetivo. Os sentidos não congruentes com a teoria de Firth são por demais aproximados para serem considerados seriamente, entretanto, este conjunto de dados parece 
ter aumentado aproximadamente na mesma razão que o total de dados em questão para o mesmo período. E também, a diferença na frequência de uso entre o nome prosódia e o adjetivo prosódico/a. Nesse sentido, os resultados parecem assinalar que um terço, ou mesmo a metade, de todos os usos do substantivo prosody nos dados não-firthianos são tópicos nos títulos da área da psicologia. Já o adjetivo prosodic, neste sub-conjunto de dados não-firthianos, só aparece em 10-20\% dos usos em títulos de publicações.

\subsection{Dicionários consultados para a elaboração deste trabalho}

Esta lista está organizada por língua e por ano de publicação. Uma vez que os grandes dicionários são normalmente obras coletivas, o autor ou o editor chefe é especificado apenas quando o nome individual figura proeminentemente como o autor que originou o trabalho. Sempre que possível, apresento o ano da primeira publicação, mesmo que em alguns casos eu tenha de fato consultado impressões posteriores que incorporaram correções editoriais.

Os trabalhos marcados com um asterisco $\left(^{*}\right)$ são aqueles cuja definição da palavra prosódia contempla, claramente, o sentido ou os sentidos linguísticos modernos discutidos neste trabalho. Trabalho sem asterisco, claramente, não contemplam tal sentido linguístico moderno. Aqueles que estão marcados com um asterisco entre parênteses dão uma definição linguística do adjetivo prosódico/a mas apenas definições tradicionais de prosódia. Olhando a lista, observa-se muito rapidamente que o sentido linguístico moderno raramente aparece em dicionários de uso geral antes de 1990.

Esta lista não pretende ser um levantamento exaustivo. Suas limitações se devem ao fato de que procurei dicionários que estivessem facilmente disponíveis para mim, por um lado, e, por outro lado, pelo fato de que eu mesmo só posso tratar com mais desenvoltura línguas românicas e germânicas.

\section{Alemão}

1967: MACKENSEN, Lutz. Deutsches Wörterbuch. Munich, Südwest Verlag. 1968: WAHRIG, Gerhard. Deutsches Wörterbuch. Gütersloh, Bertelsmann LexikonVerlag. * 1983: Duden Deutsches Universalwörterbuch. Mannheim, Duden.

1984: Der Sprach-Brockhaus, 9a edição. Munich, F. A. Brockhaus.

\section{Dinamarquês}

1939: Ordbog over det danske sprog. Copenhagen: Gyldendalske Boghandel.

*1999: Politikens Nudansk ordbog, 17a edição. Politikens Forlag. 


\section{Espanhol}

1953: VOX Diccionario general ilustrado de la lengua española. Barcelona, Spes.

1983: MOLINER, María. Diccionario de uso del español. Madrid, Editorial Gredos.

* 1991: Diccionario Anaya de la lengua. Madrid, Anaya.

* 1993: El pequeño Espasa. Madrid, Espasa Calpe.

* 1999: CLAVE diccionario de uso del español actual, 3a edição. Madrid, Ediciones SM.

* 1999: SECO, Manuel; OLIMPIA, Andrés; RAMOS, Gabino. Diccionario del español actual. Madrid, Aguilar.

\section{Francês}

1959: Petit Larousse. Paris, Larousse.

* 1966: Dictionnaire du français contemporain. Paris, Larousse.

(*) 1970: ROBERT, Paul. Dictionnaire alphabétique et analogique de la langue française. Paris, Société du nouveau Littré Le Robert.

* 1992: Dictionnaire de la langue française. Paris, Larousse.

* 2001: Le Grand Robert de la langue française, 2a edição. Paris, Dictionnaires Le Robert, VUET.

\section{Inglês}

ca. 1910: Oxford English Dictionary, 1a edition (a publicação começa em 1885; o volume que contém o termo prosody só aparece no começo do século XX). Oxford, Oxford University Press.

(*) 1961: Webster's Third New International Dictionary of the English Language. Springfield, MA, G. \& C. Merriam.

1982: Longman New Universal Dictionary. Harlow/Essex, Longman Group. 1989: Oxford English Dictionary, 2a edição. Oxford, Oxford University Press.

*Algumas vezes depois de 2002: Oxford English Dictionary. Online.

\section{Italiano}

1959: ZINGARELLI, Nicola. Vocabolario della lingua italiana, 8a edição. Bologna, Zanichelli editore.

* 1988: BATTAGLIA, Salvatore; BARBERI SQUAROTTI, Giorgio. Grande dizionario della lingua italiana. Turin, UTET. (A publicação começa em 1961; o volume contendo prosodia só aparece em 1988).

* 1999: de MAURO, Tullio. Grande dizionario italiano dell'uso. Turin, UTET.

2000: DEVOTO, Giacomo; OLI, Gian Carlo. Il dizionario della lingua italiana. Florência, Le Monnier. 


\section{Português}

1964: Dicionário prático ilustrado. Porto, Lello \& Irmão Editores.

1980: Novo dicionário compacto da língua portuguesa. Confluência / Livros Horizonte.

* 2001: Dicionário da língua portuguesa contemporânea da Academia das Ciências de Lisboa. Lisboa, Editorial Verbo.

\section{Romeno}

1975: Dicționarul explicativ al limbii române. Bucareste, Editura Academiei Republicii Socialiste România.

\section{Sueco}

* 2009: Svensk ordbok. Stockholm, Svenska Akademien.

\section{AGRADECIMENTOS}

Agradecemos a Robert Ladd sua imensa generosidade e disposição ao longo do processo tradutório, suas leituras criteriosas (assim mesmo no plural!), suas sugestões pertinentes e seus esclarecimentos de sentido na relação, nunca evidente, entre texto original e tradução. Igualmente, agradecemos a Albert Rilliard pelas diversas releituras e revisões da versão final deste texto, bem como a Carolina Ribeiro Serra pela discussão de termos de Fonologia prosódica em português, o que nos orientou na seleção das escolhas. Quaisquer resíduos de imprecisões ou interpretações errôneas são da nossa inteira responsabilidade (as tradutoras).

\section{Referências}

ALLEN, W. Sidney. Accent and rhythm. Prosodic features of Latin and Greek: A study in theory and reconstruction. Cambridge, Cambridge University Press, 1973.

ANDERSON, Stephen R. Phonology in the twentieth century: Theories of rules and theories of representations. Chicago, University of Chicago Press, 1985.

ARVANITI, Amalia. The usefulness of metrics in the quantification of speech rhythm, Journal of Phonetics, v. 40, p. 351-373, 2012.

BALTAXE, Christiane. English translation of Trubetzkoy, 1958 (q.v.), 1969.

BEAVER, Joseph C. A grammar of prosody, College English, v. 29, p. 310-321, 1968.

BECKMAN, Mary E. Stress and non-stress accent. Dordrecht, Foris, 1986.

BECKMAN, Mary E. The parsing of prosody, Language and Cognitive Processes, v. 11, p. 17-68, 1996.

BELIN, Pascal; BESTELMEYER, Patricia E. G.; LATINUS, Marianne; WATSON, Rebecca. Understanding voice perception, British Journal of Psychology, v. 102, p. 711-725, 2011. 
BOLINGER, Dwight L. Accent is predictable (if you're a mind-reader) Language, v. 48, p. 633-644, 1972a.

BOLINGER, Dwight L. (org.). Intonation. Harmondsworth, Penguin Books, 1972b.

BOLINGER, Dwight L. Intonation and its parts: Melody in spoken English. Stanford, Stanford University Press, 1986.

BRUCE, Gösta. Swedish word accents in sentence perspective. Lund, Gleerup, 1977.

CHO, Taehong; KEATING, Patricia. Articulatory and acoustic studies on domain-initial strengthening in Korean, Journal of Phonetics, v. 29, p. 155-190, 2001.

CRYSTAL, David. Prosodic systems and intonation in English. Cambridge, Cambridge University Press, 1969.

CRYSTAL, David. Glossary, in Bright, vol. 4, p. 273-348, 1992.

DAUER, Rebecca. Stress-timing and syllable-timing reanalyzed, Journal of Phonetics, v. 11, p. 51-62, 1983.

de ANGULO, Jaime. Grammatical processes: incremental vs. autonomic, Language, v. 5, p. $117-118,1929$.

FANT, C. Gunnar M. Acoustic theory of speech production with calculations based on $x$-ray studies of Russian articulations. The Hague, Mouton, 1960.

FIRTH, J. R. Sounds and prosodies. Transactions of the Philological Society, v. 47, p. 127152, 1948. Reimpr. In: Palmer (1970), pp. 1-26, 1970; reimpr. In: Makkai, p. 252-263, 1972.

FRICK, R. W. Communicating emotion: The role of prosodic features, Psychological Bulletin, v. 97, p. 412-429, 1985.

FROTA, Sónia. Prosody and focus in European Portuguese, Tese de Doutorado. Universidade de Lisboa, 1998. Publicada por Garland Press, 2000.

GIRAUD, Anne-Lise; POEPPEL, David. 'Cortical oscillations and speech processing: Emerging computational principles and operations, Nature Neuroscience, v. 15, p. 511-517, 2012.

GIRAUD, A. L.; KLEINSCHMIDT, A.; POEPPEL, D.; LUND, T. E.; FRACKOWIAK, R. S.; LAUFS, H. Endogenous cortical rhythms determine cerebral specialization for speech perception and production, Neuron, v. 56, p. 1127-1134, 2007.

GOLDSMITH, John. Autosegmental phonology. Tese de Doutorado, MIT, 1976. Distribuido por Indiana University Linguistics Club, 1976. Pubicada por Garland Press, 1979.

HALLE, Morris; KEYSER, S. J. Chaucer and the study of prosody, College English, v. 28, p. 187-219, 1966. 
HAMP, Eric. A glossary of American technical linguistic usage, 1925-1950. Utrecht/ Antwerp, Spectrum Publishers, 1957.

HARRIS, Zellig S. Morpheme alternants in linguistic analysis, Language, v. 18, p. 169-180, 1942. Reimpr. in Joos, p. 109-115, 1966.

HAYES, Bruce. The prosodic hierarchy in meter, In: KIPARSKY, P.; YOUMANS, G. (orgs.). Rhythm and meter. Orlando, Academic Press, p. 201-260. 1989.

HIMMELMANN, Nikolaus; LADD, D. Robert. Prosodic description: An introduction for fieldworkers, Language Documentation and Conservation, v. 2, p. 244-274, 2008.

HOCKETT, Charles F. A system of descriptive phonology. Language, v. 18, p. 3-21, 1942. Reimpr. In: Joos, p. 97-108, 1966; reimpr. In: Makkai, p. 99-112, 1972.

IPA. The principles of the International Phonetic Association. London, University College, 1949.

IPA. Handbook of the International Phonetic Association. Cambridge, Cambridge University Press, 1999.

JAKOBSON, Roman; WAUGH, Linda R. The sound shape of language. Berlin, Mouton De Gruyter, 1979.

JUN, Sun-Ah. The accentual phrase in the Korean prosodic hierarchy, Phonology, v. 15, p. 189-226, 1998.

KEYSER, Samuel Jay. Old English prosody, College English, v. 30, p. 331-356, 1969.

KIRBY, James P. The role of probabilistic enhancement in phonologization, In: YU, A. (org.), Origins of sound change. Oxford, Oxford University Press, p. 228-246, 2013.

LADD, D. Robert. Review of Bolinger 1986, Language, v. 63, p. 637-643, 1987.

LADD, D. Robert. 'Distinctive phones' in surface representation, In: GOLDSTEIN, L.; WHALEN, D. H.; BEST, C. T. (orgs.), Laboratory Phonology, v. 8, Berlin, Mouton de Gruyter, p. 1-26, 2006.

LADD, D. Robert. Intonational phonology. Cambridge, Cambridge University Press, 2a ed., 2008a [1996].

LADD, D. Robert. Review of S.-A. Jun (ed.) (2005). Prosodic Typology. Oxford University Press, Phonology, v. 25, p. 372-376, 2008 b.

LADD, D. Robert; REMIJSEN, Bert; MANYANG, Caguor Adong. On the distinction between regular and irregular inflectional morphology: Evidence from Dinka, Language, v. 85, p. 659-670, 2009.

LADD, D. Robert; SCOOBIE, James M. External sandhi as gestural overlap? Counterevidence from Sardinian. In: LOCAL, J.; OGDEN, R.; TEMPLE, R. (orgs.), Phonetic Interpretation: Papers in Laboratory Phonology VI. Cambridge, Cambridge University Press, p. 164-82, 2003. 
LADD, D. Robert; SILVERMAN, Kim; TOLKMITT, Frank; BERGMANN, Günther; SCHERER, Klaus R. Evidence for the independent function of intonation contour type, voice quality and $\mathrm{F} 0$ range in signalling speaker affect, Journal of the Acoustical Society of America, v. 78, p. 435-444, 1985.

LADEFOGED, Peter; BROADBENT, D. E. Information conveyed by vowels, Journal of the Acoustical Society of America, v. 29, p. 98-104, 1957.

LEBEN, William. Suprasegmental phonology. Tese de Doutorado, MIT, 1973. Publicada por Garland Press, 1980.

LEHISTE, Ilse. Suprasegmentals. Cambridge MA, MIT Press, 1970.

LIBERMAN, Mark Y. The intonational system of English. Tese de Doutorado, MIT, 1975. Publicada por Garland Press, 1979.

LIBERMAN, Mark Y.; PRINCE, Alan. On stress and linguistic rhythm, Linguistic Inquiry, v. 8, p. 249-336, 1977.

LOW, Ee-Ling; GRABE, Esther; NOLAN, Francis J. Quantitative characterizations of speech rhythm: Syllable-timing in Singapore English, Language and Speech, v. 43, p. 377401, 2000.

MCNEILAGE, Peter F. The frame/content theory of evolution of speech production, Behavioral and Brain Sciences, v. 21, p. 499-511.

MAROUZEAU, J. Lexique de la terminologie linguistique: français, allemand, anglais. Paris, Paul Geuthner, 1933.

MARTINET, André. Eléments de linguistique générale. Paris, Armand Colin, 1980 [1960]. MONRAD-KROHN, Georg H. 'Dysprosody or altered "melody of language”, Brain, v. 70, p. 405-415, 1947.

MORAES, João A. de. Intonation in Brazilian Portuguese. IN: HIRST, Daniel; DI CRISTO, Albert. Intonation Systems. Cambridge, Cambridge University Press, 1998, p.179-194.

NEAREY, Terrance M. Static, dynamic, and relational properties in vowel perception, Journal of the Acoustical Society of America, v. 85, p. 2088-2113, 1989.

NESPOR, Marina; VOGEL, Irene Vogel. Prosodic phonology. Dordrecht, Foris, 1986.

NEVINS, Andrew. Locality in vowel harmony. Cambridge MA, MIT Press, 2010.

NOREEN, Adolf. Vårt språk: Nysvensk grammatik i utförlig framställning. Lund, Gleerup, v. 1, 1903-1907.

OGDEN, Richard; LOCAL, John K. Disentangling autosegments from prosodies: A note on the misrepresentation of a research tradition in phonology, Journal of Linguistics, v.30, p. 477-98, 1994.

PALMER, F. R. Prosodic analysis. Oxford, Oxford University Press, 1970. 
PIERREHUMBERT, J. The phonology and phonetics of English intonation. Tese de Doutorado, MIT, 1980. Distribuida por Indiana University Linguistics Club, 1988.

PIERREHUMBERT, Janet; BECKMAN, Mary E. Japanese tone structure. Cambridge MA, MIT Press, 1988.

POEPPEL, David. The analysis of speech in different temporal integration windows: cerebral lateralization as "asymmetric sampling in time"', Speech Communication, v. 41, p. 245255, 2003.

RAMUS, Franck; NESPOR, Marina; MEHELER, Jacques. Correlates of linguistic rhythm in the speech signal, Cognition, v. 73, p. 265-92, 1999.

ROOTH, Mats. Association with focus. Tese de Doutorado, University of Massachusetts, 1985.

SAPIR, Edward. A type of Athabaskan relative, International Journal of American Linguistics, v. 2, p. 136-42, 1923.

SCHERER, Klaus; JOHNSTONE, R. Tom; KLASMEYER, Gudrun. Vocal expression of emotion, In: DAVIDSON, R. J.; GOLDSMITH, Davidson; SCHERER, K. R. (orgs.). Handbook of the affective sciences. Oxford, Oxford University Press, p. 433-456, 2003.

SELKIRK, Elisabeth O. Phonology and syntax: The relation between sound and structure. Cambridge MA, MIT Press, 1984.

SHRIBERG, Elizabeth; STOLCKE, Andreas. Prosody modeling for automatic speech recognition and understanding, In: JOHNSON, M.; KHUDANPUR, S.; OSTENDORF, M.; ROSENFELD, R. (orgs.), Mathematical foundations of speech and language processing. IMA volumes in Mathematics and its applications, v. 138, New York, Springer, p. 105$114,2004$.

SILVA, David. Acoustic evidence for the emergence of tonal contrasts in contemporary Korean, Phonology, v. 23, p. 287-308, 2006.

SLEDD, James. Old English prosody: A demurrer, College English, v. 31, p. 71-74, 1969.

STANDOP, E. Die Metrik auf Abwegen: Eine Kritik der Halle-Keyser Theorie, Linguistische Berichte, v. 19, p. 1-19, 1972.

SWADESH, Morris. The phonemic principle, Language, v. 10, p. 117-29, 1934. Reimpresso in Joos, p. 32-7, 1966; reimpr. in Makkai, p. 32-9, 1972.

SWADESH, Morris. The linguistic approach to Salish prehistory. New York, Columbia University Press, 1949.

THURGOOD, Graham; LAPOLLA, Randy J. The Sino-Tibetan languages. London/New York, Routledge, 2003.

TRAGER, George L.; BLOCH, Bernard. The syllabic phonemes of English', Language, v. 17, p. 223-46, 1941. 
TRUBETZKOY, Nikolai Sergeevich. Grundzüge der Phonologie. Göttingen, Vandenhoeck \& Ruprecht, 1958 [1939]; tr. C. Baltaxe como Principles of phonology. University of California Press, 1969; tr. Jean Cantineau como Principes de phonologie. Paris, Klincksieck, 1949.

TURK, Alice; SHATTUCK-HUFNAGEL, Stefanie. Multiple targets of phrase-final lengthening in American English words, Journal of Phonetics, v. 35, p. 445-72, 2007.

WHITE, Laurence; MATTYYS, Sven L. Calibrating rhythm: First language and second language studies, Journal of Phonetics, v. 35, p. 501-22, 2007.

WIMSATT, W. K. 'The rule and the norm: Halle and Keyser on Chaucer's Meter', College English, v. 31, p. 774-88, 1970.

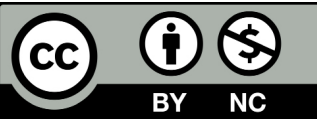

Data de submissão: 15/01/2018

Data de aceite (do direito autoral da trad.): 31/07/2018 